International Journal of Social Inquiry Cilt / Volume 14 Sayı / Issue 22021 ss./pp. 617-660

\title{
BITHYNIA BÖLGESİ ROMA DÖNEMİ MİMARİ BETIMLİ KENT SİKKELERİ
}

\section{Metehan İHTİYAR*}

Makale Geliş Tarihi-Received: 15.03.2021

Makale Kabul Tarihi-Accepted: 10.10.2021

DOI: 10.37093/ijsi.1019657

\section{ÖZ}

Antik Bithynia, kuzeyde Pontus Euxenios, batıda Hellespontos ve Rhyndakos, güneyde Sangarios nehri ile sinırlanan, Küçük Asya'nın kuzeybatı köşesindeki bir bölgedir. Bithynia Bölgesi Helenistik Dönem'de bağımsız bir krallık olarak kurulmuş ve daha sonra MÖ 74 yılında Roma Imparatorluğu'nun bir eyaleti haline gelmesiyle birlikte doğu sinırlarn genişlemiştir. Bithynia Eyaleti, Roma yönetimine geçmesiyle birlikte bölgede imar faaliyetleri başlamıs ve bu kapsamda kent surları, tapınaklar, tiyatrolar, fener kuleleri, gymnasion ve antsal binalar gibi mimari yapilar inşa edilmiştir. Şehirlere ait bu mimari doku Bithynia kentleri adına basılan birçok sikkenin arka yüzünde Roma Imparatorlarının finansal yardımı sayesinde siyasal propaganda amaci ile betimlenmiştir. Mimari betimli sikkelere göre tapınaklar, Bithynia kentlerinde saygınlı gören Dionysos, Demeter, Asklepius, Apollon, Herakles ve Fortuna gibi tanrı ve tanriçaların yanı sıra kentlerde imparatorlar onuruna gerçekleştirilen agon oyunları ve bayramlar için inşa edilmiş olduğu anlaşılmaktadır. Tasvir edilen birçok yapının lokasyonu belli değildir. Ancak en azından benzer kent planları ile yapılan karşılaştırmalara göre muhtelif tapınakların Bithynia kentlerinde

* Bursa Uludă̆ Üniversitesi, Sosyal Bilimler Enstitüsü, Arkeoloji Tezli Yüksek Lisans Programı Mezunu, Bursa/Türkiye. metehanihtiyar08@gmail.com, ORCID: https://orcid.org/0000-0003-4573-1571. 


\section{Metehan İHTİYAR}

bulunan mevcut kiliselerin temellerinde veya çevresinde aranması gerektiği düşünülmektedir.

Sonuç olarak bu makalede özellikle Roma Dönemi'nde ortaya çıkan mimari betimli sikkeler ışında, Bithynia Bölgesi'nde yer alan kentlerin yapı programı incelenmiş ve bununla ilgili fikirler öne sürülmüştür.

Anahtar Kelimeler: Bithynia, Roma Dönemi, Sikke, Nümizmatik, Mimari. 


\title{
ARCHITECTURAL DEPICTED COINS OF CITIES IN THE REGION OF BITHYNIA DURING THE ROMAN PERIOD
}

\begin{abstract}
Ancient Bithynia is a region in the northwest of Asia Minor, bounded by Pontus Euxenios to the north, Hellespontos and Rhyndakos to the west, and the Sangarios river to the south. The Bithynia Region was established as an independent kingdom in the Hellenistic period and thereafter became a province of the Roman Empire in 74 BC. Thus, the eastern borders of the province expanded. After the Provincia of Bithynia came under the rule of Roman Empire, reconstruction activities started in the region and within this scope, monumental structures such as city walls, temples, theaters, lighthouses, port structures and gymnasions were built. This architectural texture of the cities is depicted on the reverse of many coins minted in the name of the cities of Bithynia, for the purpose of political propaganda, thanks to the financial assistance of the Roman Emperors. According to the coins with architectural depictions, the temples were dedicated to gods and goddesses such as Dionysus, Demeter, Asclepius, Apollon, Heracles and Fortuna, who were respected in the cities of Bithynia. In addition, it is understood that these temples were built in the name of the agon games performed for the emperors. The location of many of the structures depicted is unknown. The location of many of the structures depicted is unknown. However, according to the comparisons made with similar city plans, it is thought that the temples may be on the foundations of the existing churches in the cities of Bithynia.
\end{abstract}

As a result, in this article, the building program of the cities in the province of Bithynia was examined in the light of the coins with architectural depictions in the Roman Imperial period.

Keywords: Bithynia, Roman Period, Coin, Numismatic, Architecture. 


\section{GİRIŞ}

Makalenin konusunu; Bithynia Bölgesi'nde bulunan kentlerin, Roma Dönemi'nde darp edilmiş mimari betimli sikkleri oluşturmaktadır. Nümizmatik biliminde mimari betimler dönemin ihtişamlı yapılarını sikkeler üzerinde gösteren tipleridir. İlk olarak Roma Cumhuriyeti Dönemi'nde ortaya çıan ve imparatorluk dönemiyle birlikte yoğunluk kazanan mimari betimli sikkeler, Roma eyaletlerinin belirleyici unsurlarından olan tanrı ve tanrıçalar, imparatorlar ve onların onuruna düzenlenen bayram oyunlarıyla ilişkili olarak basılmışlardır. Önceleri yalnızca bir ödeme aracı olan madeni paralar Roma Dönemi'nde mimari betimlerin de ortaya çıkmasıyla birlikte hem bir haber kaynağı olarak hem de siyasal propaganda aracı olarak kullanılmışlardır. Antik Bithynia Bölgesi Roma yönetimine girmesiyle birlikte imparatorluğun bir eyaleti haline gelmiş ve bununla birlikte birçok sosyal, kamusal ve dini yapı inşa edilerek imar faaliyetlerinin merkezi olmuştur. Roma egemenliğindeyken inşa edilen bu yeni yapılar Bithynia Bölgesi'ndeki antik şehirlerde basılan sikkelerde sıkça tasvir edilmiştir.

Bitnynia Bölgesi sınırları içerisinde sikke basıtığı bilinen birçok Roma kenti vardır. Ancak makale kapsamına yalnızca mimari betimli sikke basan kentler ele alınmıştır. Bu kentler coğrafi olarak batıdan doğuya doğru Kaisereia Germanika, Kalkhedon, Prusa ad Olympum, Nikaia, Nikomedeia, Prusias ad Hypium, Herakleia Pontika, Bithynion/Claudiopolis, Iuliopolis, Tios, Kretia/Flaviopolis olarak sıralanmaktadır (Resim 1). Mevcut çalışmada Roma İmparatorluk Dönemi'nde Bithynia sınurları içerisindeki bu kentlerde yer alan mimari betimli sikkelerden yola çıkılarak kaybolmuş yapılar veya bir kısmı günümüze kadar gelmiş olan mimari yapılar incelenecektir. Bu kapsamda mimari tipler temel alınarak dönemin muhtelif yapılarının lokasyonu hakkında düşünceler ileri sürülecek ve bölgenin yap1 faaliyetlerini incelenecektir. Makale konusunun içeriğini oluşturacak olay, olgu ve bilgileri daha netleştirmek adına öncelikle Bithynia Bölgesi'nin kısaca tarihi ve mimari betimli sikkeleri bilimsel anlamda incelemek yerinde olacaktır. 


\section{BITHYNIA BÖLGESI'NİN TARİHİ}

Coğrafi konumu nedeniyle, Asya ile Avrupa arasındaki geçiş yolarının kavşağında yer alan Bithynia Bölgesi, tarihin her döneminde önemli yerleşim yerlerini bünyesinde barındırmıştır. Tarih öncesi dönemlerden, Pers hâkimiyetine, kolonizasyon döneminden Helenistik Dönem‘e ve daha sonra Roma ve Bizans Dönemlerine kadar Bithynia Bölgesi önemli tarihi olaylara şahitlik etmiştir. Bithynia Roma hakimiyetinden önce, Propontis (Marmara) denizinin ve Bosphoros'un (İstanbul Boğazı) doğu kiyılarını ve Pontus Euksenios'un (Karadeniz) batı kisminı kapsayan, Anadolu'nun kuzeybatısındaki bölgeyi kapsamaktaydı. MÖ 74'te Bithynia'nın vasiyet yoluyla Roma İmparatorluğuna eklenmesiyle birlikte Bithynia ve çevresi de Roma egemenliğine girmiş ve bölgenin esas sınırları belirlenmiştir (Kaya, 2005: 17). Roma'nın VI. Mithridates'i ortadan kaldırmasıyla birlikte MÖ 63'te bölgeye gönderilen General Pompeius burada yaptığı yeni düzenlemeler kapsaminda Pontus'un batısı ile Bithynia Bölgesini birleştirilmiş ve "Provincia Bithynia et Pontus" adı altında yeni bir eyalet oluşturmuştur. Böylelikle antik dönemde Küçük Asya'nın kuzeydoğusunda küçük bir bölge olan Bithynia, Roma İmparatorluk Dönemi'nde, Roma'nın Anadolu'daki en büyük eyaletlerinden biri olmuştur. Eyaletin özellikle doğusunda sınırları sabit olmayan her imparatorla birlikte değişen kentleri belirmele konusunda sıkıntı yaşansa da bu makalede Bithynia ile ilintili Herakleia Pontika ve Tios kentlerine ait mimari betimli sikkeler de incelenmiştir. Strabon'a göre Herakleia Pontika ve Tios kentleri Bithynia ile ilintili Pontus kentlerinden biri idi (Strab. XII. 3). İmparator Traianus, imparatorluk eyaleti haline getirdiği Bithynia'da MS 111'de Plinius Caecilius Secundus'u (Genç Plinius) eyalet valisi olarak görevlendirmiştir. Proconsul Plinius görev yaptığ1 2 y1l boyunca başta Prusa ve Nikaia olmak üzere eyaletin farklı kentlerindeki yerel yönetim sorunları ve bayındırlık problemleri ile yakından ilgilenmiştir (Plinius, Epistulae, X.41). Bu dönemde Vali Plinius mükemmel idareciliği ile bölgedeki kentlerde geniş imar faaliyetlerinde bulunmuş ve bölgenin ekonomik açıdan gelişmesini sağlamıştır. İmparator Hadrianus Bithynia'ya tekrar gelerek MS 120 yılında meydana gelen depremde yıkılan Nikaia ve Nikomedeia kentlerine yardımlarda bulunduğu bilinmektedir (Eus. 198.9). İmparatorluk döneminde bölgede gelişen tüm bu imar faaliyetleri ve imparatorların gezileri sikke darplarındaki mimari çeşitliliği oldukça etkilemiştir. MS 257-258 yıllarına gelindiğinde ise kuzeyden gelen 
Gothlar başta Nikaia ve Nikomedeia olmak üzere bir çok Bithynia kentini yağmalamıştır (Zos.1.73.2; Kaya, 2000: 145). Bu nedenle İS 3. yüzyıldan sonra Bithynia eyaletinde sur tahkimatları başlamış ve sikke arka yüzlerinde tapınak yapılarından çok sur betimlieri ve kent kapıları görülmeye başlanmıştır.

\section{BİLIMMSEL ANLAMDA MIMMARİ BETİMLİ SİKKELER}

İlksel örnekleri MÖ 4. yüzyıla kadar gitmesine rağmen Roma İmparatorluk Çağı'nda devletin askeri ve ekonomik anlamdaki gelişimine paralel olarak sayıca zirveye çıkan mimari betimli sikkeler, eyaletler ile merkez Roma arasındaki politik propagandaların öncüsü olmuş ve böylece antik çağ toplumları için bir iletişim aracı görevi de üstlenmiştir. Bu genel yaklaşımın yanı sıra mimari betimli sikkleler özellikle, kentsel, politik, dini, mitolojik, estetik ve kültürel olarak da anitlara tanıklık eden bir bilgi potansiyeli olarak karşımıza çıkmaktadır (Filges, 2015: 2). Roma Çağı'nda bir yerleşimi kent yapan tüm mimari ögeler sikkelerin arka yüzlerinde kendilerine yer bulmuş ve bunlar o dönemlerdeki şehirlerin zenginliğini ve yapı aktivitelerini resmetmişlerdir (Trell, 1976: 7). Sikkleler üzerindeki mimari tasvirler hakkında üzerinde durulması gereken bir diğer konu da bu tasvirlerin uygulamasında kullanılan yöntemlerdir. Her biri farklı sanatsal zevklere ve değişken bakış açılarına sahip olan sikke ustaları darp ettikleri sikkelerde benzer yapıların farklı detayların farklı metotlarla vurgulamışlardır. Bu yöntemlerden en sık kullanılanı tapınak sütun sayılarının kısaltılmasıdır (Trell, 1976: 10). Bu yöntemin uygulandığı Ephesos kentindeki sikkelerde Diana Tapınağı, birkaç sikke üzerinde farklı sütun sayıları ile gösterilmiştir (Resim 2). İlk serideki tasvirde oktasylos tapınağın ön cephesinde duran kült heykeli, diğer seride orta sütunları kaldırılmış olan dört sütunlu bir öncephede durmaktadır. Görüldüğü üzre normalde ön cephesinde sekiz sütun barındıran Diana tapınağı, kült heykelinin sikke tasvirinde daha geniş yer edinmesi için farklı sütun sayıları ile birlikte gösterilmiştir. Bu konuda diğer bir nümizmatik kural da tasvire derinlik alg1sı kazandıran "arka yerine yukarıda" kuralıdır. Bu uygulamanın kullanıldığı tasvirlerde mimari yapının arka cephesi iç kısmında ya da yukarıda gösterilmekteydi. Bununla ilgili Sidon kentindeki bir Elagabalus serisinin arka yüzünde üç bölümden oluşan Astarte Tapınağı betimlenmektedir (Resim 3). Söz konusu tapınak burada esasen iki sütunun arkasında bulunmaktadır. Burada arka kısımda bulunan bölüm tapınağın üstünde gösterilmiştir. $\mathrm{Bu}$ durum 
nümizmatik bir yöntem olan "above instead of behind" yani "arka yerine yukarıda" olarak bilinmektedir (Trell, 1976: 11). Nümizmatiğin bu akılcı yöntemi sayesinde tapınak ve içindeki figüratif objeler sütunların üzerinde gösterilerek tasvire derinlik algısı kazandırılmıştır. Bithynia Bölgesine yer alan Roma kentlerindeki mimari betimli sikkelerin tasarımında da çoğunlukla bu kısaltma yöntemleri uygulanmıştır.

\section{BITHYNIA KENT SİKKELERİ ÜZERİNDEKİ MİMARİ BETIMLER}

Konumuzun coğrafi sınılarını teşkil eden Bithynia Bölgesi'nin tarihi ve mimari sikkeler hakkında verilen bu genel bilgilerin ardından, antik ve modern literatürden edinilen bilgilere göre bölge coğrafyasında sikke bastı̆̆ 1 anlaşılan kentlere ait mimari sikke tipleri detaylı bir şekilde ele alınacaktır.

\subsection{Kaisereia Germanika / Trilye-Kapanca}

Yakın zaman kadar yapılan araştırmalara bakıldığında lokasyonu tartışmalı kentlerden birisi olan Kaisereia Germanika kenti yazılı belgelere göre Bithynia sınırları içerisinde kurulmuştur (Doğancı, 2007: 146). Antik yazarlardan çok az bilgi alabildiğimiz kent hakkında, Yaşlı Plinius, Rhyndacus ile Apamea arasında bir yerde kurulmuş olduğunu yazmıştır (Plin. Nat. V 143). Ancak Ptolemaios da Kaisereia'yı iç kısımlardaki kentler arasında tanımlamıştır (Ptol. Geogr. V 1.14). Bu nedenle antik kaynaklara göre şehrin kesin lokasyonu tutarsiz ve belirsizdir. Bu noktada Kaisareia Germanika için kentin lokasyonu hakkında önemli detaylar içeren liman tasvirli sikkeler oldukça önem taşımaktadır.

\subsubsection{Liman Tasvirleri}

Kaisareia Germanika sikkelerindeki liman betimli sikkeler kentin lokasyonu hakkında konuya açıklık getirmektedir. Bu düşünceler için önemli olan sikkeler Pescennius Niger ve Septimius Severus yönetiminde darbedilmiştir (Resim 4-5). Her iki liman tasvirli sikke üzerinde giriş kısmı iki dalgakıran ile çevrili olan dairesel veya omega şeklindeki liman yapısı kompleksinin kuş bakışı görünümü verilmiştir. Sikke tasvirlerdeki ortak detaylar arasında liman girişinin 
karşısına inşa edilmiş bir deniz feneri ve üzerine Nike yerleştirilmiş bir sütun yer alıyor. Tasvirde limanın kenarında görülen distylos öncepheye sahip bir bina köşe sütunları ve kırma çatısıyla birlikte bir tapınak izlenimi vermektedir (Price, Trell, 1977: 40). Bazı araştırmacılara göre Pescennius Niger sikkesindeki tasvirde geminin yelkenleri indirilmiş olduğu için bir ticaret gemisi resmedilirken, Septimius Severus serisindeki tasvirde ise yelkenler kaldırılmış halde olduğu bir savaş gemisi temsil edilmek istenmiştir (Şahin vd., 2011: 220). Farklı tiplerdeki geminin tasvirleri liman yapısının hem askeri hem de sivil amaçlar için kullanıldığını düşündürmektedir. Söz konusu sikkeler Kaisereia Germanika'nın lokalizasyonunu kesin olarak deniz kenarında ya da iç kesimde olduğunu göstermese de, Marmara'daki bir limanla bağlantılı olabileceğine işaret etmektedir. Mudanya ilçesine bağlı Zeytinbağı Beldesi üzerindeki Kapanca bölgesinde yapılan araştırmalar bu konuya açıklık getirmektedir. Bölgenin Marmara Denizine uzanan bölümünde koruma duvarları kaba ve sertleşmiş bloklardan oluşmakla birlikte kıyıdan itibaren yüzeye çıkıldığında düzgün kesilmiş taş blokları ve birçok keramik ve cam parçası görülmektedir (Resim 6). Kaisereia Germanika'nın liman havzasında bulunan büyük taş blokları burada yerleşim kalıntılarına göre yaklaşık 3 metre zemin altına olması beklenen kent surlarının başlangıcını oluşturduğunu düşündürmektedir (Şahin vd., 2011: 223). Yüzeyde görülen tüm bu yapı elementleri şüphesiz omega formundaki yapay bir limanın parçalarını teşkil etmektedir (Resim 7). Yüzeydeki tarihlenebilir buluntulara göre ise Kapanca Limanı'nın kullanımı Geç Roma Dönemine tekabül etmektedir (Şahin vd., 2011: 222). Sonuç olarak burada belirtilen tüm nümizmatik ve arkeolojik deliller Kaisereia Germanika kentinin limanı ve kentsel lokasyonu hakkında önemli ipuçları sağlamıştır. $\mathrm{Bu}$ alanda ileride gerçekleştirilecek olan çalışmalar genel yerleşim planına ilişkin ilk ipuçlarını edinmemizi sağlayabilecektir.

\subsubsection{Amphitiyatro/ Circus Tasvirleri}

Kaisereia Germanika sikkelerinde bir diğer mimari konulu tip amphitiyatro tasvirleridir. Bununla ilgili Severus Alexander adına darbedilmiş sikkeler ön cephesi kalkanlarla süslenmiş içi seyirci dolu dairesel yapıyı canlandırmaktadır (Resim 8). Antik dünyanın bilinen en ünlü amphitiyatrosu Colloseum ile kıyaslandığında yapı son derece basitleştirilerek tasvir edilmiştir. Oturmuş oldukları için sadece bel izasına kadar görünen izleyiciler yapıya göre daha büyük boyutlu 
yapılmışlardır. Giriş kapısı veya oturma kademeleri belirgin değildir. Yuvarlak binanın altında bulunan koni şeklindeki işaret Meta'dır ${ }^{1}$. Meta'nın yuvarlak yapı ile birlikte görülmesi Kaisereia Germanika'da amphitiyatronun yanı sıra bir circus yapısı bulunduğuna da işaret eder. Circuslar, içinde at ve araba yarışlarının yapıldığı bir tarafı yarım daire şeklinde olan ince ve uzun yapılardır (Er, 2006: 252). Meta'nın sahanın iç kısmına değil, sembolik olarak yapının alt boşluğuna yerleştirilmiştir. Bunun nedeni olasılıkla sikke yuvarlağının söz konusu yapının detaylı gösterilmesi için yetersiz kalmasıdır. İçerisinde çeşitli agonistik oyunların düzenlendiği yerleri gösteren betimlerin sikkelerde yer alması Kaisereia Germanika kentinde imparator adına düzenlenen onursal gösteriler ile ilişkili olmalidir.

\subsection{Kalkhedon / Kadıköy}

Kalkhedon kenti Byzantium'un karşısında bir Megara kolonisi olarak Bosphoros üzerinde kurulmuştur (Strab. XII.4.2). Kalkhedon toprakları bugünkü Kadıköy İlçesi sınırları içerisinde kalmaktadır (Resim 1). MÖ 74 yılında diğer Bithynia kentleri gibi yeni kurulan Bithynia-Pontus Eyaletine dâhil edilen kent, Klasik Çağ'dan MS 3. yüzyıla kadar sikke basmıştır (RG, 1908: 98). Kentin Roma İmparatorluk Çağı'na ait sikkeleri üzerinde genellikle Apollon betimi, tapınak, tripod, lir gibi çeşitli tasvirlere yer verilmiştir (RG, 1908: 288289). Ancak mimari betimli sikkelerde yalnızca Apollon'a adanan tapınak yapısı resmedilmiştir.

\subsubsection{Apollon Betimli Tapınak}

Apollon Tapınağı betimleri Kalkhedon kentinde İmparator Elagabalus Dönemi'nde darbedilen sikkelerin arka yüzünlerinde yer almaktadır (RG, 1908: 304, No.91). Elagabalus sikkesindeki tasvirde, iki krepisli bir podyum üzerinde yükselen tetrastylos tapınağın öncephesi resmedilmiştir (Resim 9). Üzerindeki yivlerin oldukça berligin olduğu görülen sütunlar bir kaide üzerine oturmakta ve başlıkları korint düzenindedir. Entablatürde üçgen formdaki alınlığın altında düz olarak devam eden arşitrav kült heykelinin üzerinde yarım daire bir

1 Meta, Circuslarda yarış arabalarının dönüşünü belirleyen kısa sütunlar şeklindeki sınır işaretidir (Er, 2006:252). 
kemer teşkil etmiştir. Apollon'a ait kült heykeli geniş bırakılan orta sütunlar arasında ayakta, sola dönük şekilde durmaktadır. Burada Apollon sol eline khlamysini dolamış, sağ elinde bir dalı sunağın üzerine tutarak bir şeyler boşaltır şekilde sunu yapmaktadır. C. Bosch, Apollon tapınımila ilgili olarak bu kültün Kalkhedon'a Nikomedeia'dan gelmiş olduğunu ve bunun nedeni ise Nikomedeia kentinin kurulduğu yerde daha önce bulunan Astakos kentinin bir dönem Kalkhedon'dan gelen sömürgecileri barındırmış olmasına bağlamaktadır (Bosch, 1935: 269).

\subsection{Prusa Ad Olympum / Bursa}

Antik Çă̆' da Bithynia'nın önemli kentlerinden birisi olan Prusa kenti Mysia Olymposu'nun (Uludağ) kuzey yamaçlarında kurulduğundan Prusa ad Olympum olarak adlandırılmıştır (Strab. XII 4.3). MÖ 74'te IV. Nikomedes' in Krallığı Roma'ya birakmasıyla Prusa ad Olympum kenti de Bithynia Eyaletine bağlanmıştır (Macro, 1980: 665). Prusa, Iulianus ve ailesi için sikke basan tek merkezdir (Sear, 1982: 197). Sikkeler de genellikle bu zaman dilimi içerisinde basılmıştır. Bu dönemde darbedilen sikkeler üzerinde mimari betim olarak genellikle tapınak ve thermae tasvirleri görülmektedir.

\subsubsection{Tapinak Betimleri}

Prusa sikkelerindeki mimari tasvirlerde genellikle cephesi altı sütunlu yani hexastylos tapınaklar hâkimdir. İmparator Pertinax (MS 193) adına darbedilen bir seride hexastylos tapınak cephesine yer verilmiştir (Resim 10). Tasvirde üçgen alınlığın ortasına bir clipeus (yuvarlak kalkan) ve tepesine akroter yerleştirilmiştir. Tapınak iki krepisli (basamak) bir podyum üzerinde ve ion sütunları ile yükselmektedir. Bir Iulia Paula sikkesinde ise aynı tapınak modeli içerisinde bir kült figürü ile birlikte gösterilmiştir (Resim 11). Sikke tasvirinde cephesi altı sütunlu tapınağın iç kısmında oturur haldeki kült heykeli, sola dönük, sol elinde asa ve sağ elinde bir patera tutmaktadır. Atribülerinden anlaşıldığı kadarı ile kült heykeli Zeus'a ait olmalıdır. Alınlık kısmı silinmiş olduğundan dolayı pek seçilememektedir, ancak Requeil Général'deki açıklamasına göre orta sütunlar üzerinde bir kemerli geçiş olduğu anlaşılmaktadır (RG, 1912: 593, No.7). Sonuç olarak bu iki tapınak tasvirine genel olarak bakıldığında Prusa kentinde ion düzeninde cephesi altı sütunlu bir Zeus tapınağının varlığı kabul edilebilir bir görüştür. 


\subsubsection{Thermae Betimi}

Sikke tasvrilerine göre tapınakların yanı sıra yine kentte var olduğu anlaşılan bir diğer mimari yapı kentin zengin su kaynaklarıyla ilgili olduğu düşünülen Thermae tasviridir. Iulia Mamea adına darbedilen bir bronz sikkenin arka yüzünde dört sütunlu bir giriş kapısı olan, kırık bir arşitrava sahip ve üçgen alınlık taşıyan bir yapı cephesi resmedilmiştir (Resim 12). Tasvirde karşılıklı uzanmış yatan iki kadın figürü binanın önüne yerleştirilmiştir. Bunların arasında ağızlarından sular akan, dışarıya doğru eğimli testiler bulunmaktadır. Tasvir tetrastylos tapınak cepheleri ile benzerlik gösterse de testileri, akarsuları ve kadın figürleri sebebiyle tamamen farklı bir özellik taşımaktadır. Imhoof-Blumer ve Christian Marek bunların pinarların başında duran nehir tanrıçalarını (Hypios) temsil ettiğini ve yapının MS 3. yüzyıl imparatorluk hamamı olabileceği üzerinde durmuştur (Imhoof-Blumer, 1924: 173-421; Marek, 2003: 80). Yapının lokasyonu hakkında Prusalı hatip ve yazar Dion Chrysostom (MS 40-120) ve Genç Plinius Traianus'a yazdığı mektuplar bizi aydınlatmaktadır. Dion Chrysostom yaşadığı dönemde Bursa'da eski yapı ve kutsal alanların yıkılarak sütunlu giriş kapıları ve su kemerleri gibi yeni yapılarla kentin donatıldığına değinirken (Dion Chrys. XXXVIII/36), Plinius mektuplarında Prusa'ya yeni bir hamamın inşaasından bahsetmektedir (Plin. Epist. X 37). Yapının, Bursa'nın kuzeybatısında, ovadan yaklaşık 100 metre daha yukarda olmak üzere günümüzde zengin termal kaynaklarının bulunduğu Çekirge semtinde olduğu tahmin edilmektedir.

\subsection{Nikaia / İznik}

Günümüz İznik sınırları içerisinde yer alan Nikaia kenti, Askanius (İznik) gölünün doğu ucunda Sangarius (Sakarya) irmağının 25 km. batısında yer almaktadır (Resim 1). MÖ 66'da Roma senatosunun doğuda özel bir yetkiyle görevlendirdiği Pompeius'un MÖ 63'te Bithyia-Pontus Eyaletini kurmasıyla birlikte Nikaia kenti de bu yeni eyaletin kentlerinden biri olmuştur (Macro, 1980: 665; Doğanc1, 2007: 71). Özellikle MS 2. ve 3. yüzyıllarda yaşanan Nikaia ve Nikomedeia kentleri arasındaki unvan mücadelesi Nikaia kentinde büyük ölçekli kamusal, dini, askeri ve siyasi içerikli birçok yapı inşa edilmesine zemin hazırlamış ve bu durum kent sikkelerinde mimari tiplerin yoğunluk kazanmasına sebep olmuştur. Kentin mimari dokusu 
hakkında son derece önemli detaylar veren sikke tiplerinde en çok öne çıkanlar kenti çevreleyen sur betimleri olmuştur.

\subsubsection{Kent Surlarını Gösteren Betimler}

Bugün hala büyük bir kısmı ayakta olan Nikaia surları, kenti çevrelemekle birlikte gölden ve etrafındaki ovadan gelecek tehlikelere karşı kenti korumak üzere Helenistik Dönem'de inşa edilmişlerdir. Mevcut sur yapısı kentin ilk kurulduğu Helenistik Dönem'den olmadığı anlaşılmaktadır. Roma Dönemi'nde Flaviuslar hanedanlığından günümüze kadar varlığını sürdüren Nikaia surları yapılmıştır (Şahin, Mert, 2011: 175). Sikke tasvirlerine genel olarak bakıldığında Nikaia'yı çevreleyen surların kuş bakışı görünümü perspektif açıdan verilmiş olduğu görülmektedir (Resim 13). Betimlerde kenti oktagon şeklinde çevreleyen surların her biri büyük kuleler ile tahkim edilmiş olduğu görülmektedir. Kent surlarının dört kapısı olmasına rağmen tasvirde birbirine bakışımlı iki sur kapısı gösterilmiştir. Surlara ait diğer kapılar ise perspektif kurallara göre görülmemesi gereken kenarlarda yer almaktadır. Daha geniş açı ile gösterilen ön kapı üç yarım daire kemer ile birlikte çevrilmiştir. Kapının her iki yanında büstlerin konulduğu nişler bulunmaktadır. Surların merkezindeki boşluk APIET $\Omega$ N MEГ lejandına ait harflerin yerleştirildiği alanı oluşturur (Weiser, 1983: 88-91). Bu dönem sur betimli tasvirlerin üzerinde bulunan "Magiston" ve "Ariston" sifatları "En İyi ve En Büyük" anlamlarında kullanılmıştır (Donaldson, 1965: 323). Bu sıfatların sikke tasvirlerinde gösterilmesinin nedeni olasılıkla MS 258' deki Goth istilasından sonra Gallienus Dönemi'nde yeniden imar edilen surlar için imparator adına düzenlenen agon oyunlarıdır (Leschhorn, 1998: 49-196). Nikaia surları söz konusu sur betimli sikkelerin basıldığı dönemden çok önce inşa edildiği için tasvir edilen sur betimleri yeni bir inşa faaliyetini değil, Gallienus ve Claudius Gothicus dönemi aralığında gerçekleştirilen sur tahkimatlarına ve restorasyonlara işaret etmekte olduğu söylenebilir.

\subsection{2. Çok Katlı Anıtsal Yapı Tasvirleri}

Nikaia sikkelerindeki bir başka mimari konu çok katlı binaları temsil eden anıtsal yapılardır. Bununla ilgili İmparator Claudius ve eşi Messalina adına basılan bronz sikkelerin arka yüzlerinde iki katlı mimari yapı tasvirlerine yer verilmiştir (Resim 14). Sikke betimlerine göre yapı, yüksek bir stylobat üzerinde, dört sütunla birlikte 
yükselmektedir. NEIKAIEQN lejandı iki kat arasına veya alınlık kısmına yerleştirilmiştir. Alınlık kısımları ise bazen üçgen şeklinde, bazen de alışık olunmayan bir şekilde yarım daire formatındaki kemerle üç kısma ayrılmıştır. C. Bosch'a göre sikkedeki tasvirde binanın her iki yanında bayram oyunlarıyla ilişkili olarak toplam dört adet agonistik zafer tacı ya da ödül tacı olarak nitelendirilen objeler betimlenmiştir (Bosch, 1935: 233). Bu nedenle burada özellikle son örnekte görülen zafer taçlarının resmedilmesinden dolayı M. Anabolu tarafından bu yapı Gymnasion olarak tarif edilmiştir (Anabolu, 1952: 249). Oyunların ancak Gymnasion ve Stadion gibi halka açık binalarda yapılabildiği bilinmektedir. Ayrıca Strabon'un eserinde ve Genç Plinius'un mektuplarında geçen Nikaia'daki Gymnaison ifadeleri de akla bunu getirmektedir (Strab. XII. 4.7; Plin. Epist. X, 3940). Fakat açıkça bir anıtsal yapı karakterine sahip olmasına rağmen yapının inşa nedeni hakkında kesin bir şey ileri sürmek şimdilik olanaksızdır.

İki katlı anıtsal yapıların yanı sıra bir Nikaia sikkesindeki Septimius Severus bronzunda alışık olunmayan bir tasvir daha karşımıza çıkmaktadır (Resim 15). Cephede dört sütunlu olarak görülen bu binanın alınlık kısmı karmaşık bir mimari kompozisyonla verilmiştir. Yapının üst katında herhangi bir sütun yoktur ancak sütun aralıklarına denk gelen kısımların üzerinde üç adet bölme şeklinde yerleştirilmiş pencere aralıkları bulunmaktadır. Öncephede sütunlar arasında kaide üzerinde üç heykel görünmektedir. Bu tip figürlerin agon oyunlarının galiplerini temsil ettiğin düşünülmektedir. Bu tür oyunların galibine oyunu kazandığı kentte veya doğduğu şehirde bir heykel dikilir, bu heykellerin kaidesine ismi, kazandığı spor dalı ve zaferleri kazılırdı (Bosch, 1948:1vd.). Ayrıca sikkenin arka yüzünde yer alan CEOYHPEIA lejandı merasim oyunları ile ilgili olduğunu gösterir (Erol, Özdizbay, 2011: 323, Lev.28: S.31). Ancak yapının açıkça Claudius serilerindeki gibi çift katlı olup olmadığı anlaşılamamıştır. $\mathrm{Bu}$ tasvirdeki yapı eğer tek katlı bir tapınak ise olasılıkla Nikaia sikkelerindeki Severuslar hanedanlığı döneminde yoğunlaşan tetrastylos tapınak tasvirleri ile ayn yapıyı temsil ediyor olmalıdır (Resim 16). Bu nedenle bu tapınak betimlerinin MS 2. yüzyılda Nikaia'da düzenlenen Severia oyunları adına inşa edilmiş imparator tapınağını temsil ettiği şeklinde yapılan yorumlar (Bosch, 1935: 119) akla yatkın görünmektedir. 


\subsubsection{Tapınak Betimleri}

Nikaia kentine ait sikkelerin arka yüzlerinde mimari çeşitliliğin en fazla olduğu yapı türü tapınaklardır. $\mathrm{Bu}$ tapınakların mimari tasvirlerin ikonografisine göre Dionysos, Asklepios ve Tykhe (Fortuna) olmak üzere üç farklı tanrı ve tanrıçaya adanmış olduğu anlaşılmaktadır. Bunlardan tapınak lokasyonu hakkında yorum yapılabilen tasvirler Dionysos ve Asklepius'a aittir. Antik yazarlar ve yazıtlar tarafından kentin efsanevi kurucusu ve baş tanrısı olarak bahsedilen ${ }^{2}$ Dionysos'a adanan tapınak tasvirleri M. Aurelius ve Lucius Versus sikkelerinde görülmektedir (Resim 17). Her iki sikke betiminde de cepheden resmedilen tetrastylos tapınağın içerisinde bir kült heykeli görülür. Figür, ayakta ve sola doğru durmakta, sol elinde thyrsos ve sağ elinde kantharos tutmaktadır. Tapınağın üçgen alınlığıda Dionysos'un kutsal hayvanlarından yılanlarla bezenmiştir. Buradaki yılan yeniden doğuşu ve bilgeliği temsil etmektedir (Boyana, 2016: 48). Atribüleri ve duruş özelliğinden dolayı kült heykelinin Dionysos'a ait olduğu ve tapınağında ona adanmış olduğu söylenebilir.

Dionysos'u tasvir eden sikkelerden tapınağın mimarisi hakkında bilgi edinmemize rağmen yapının lokasyonu hakkında herhangi bir veri bulanmamaktadır. Ancak Nikaia kentinin çağdaşı benzer hippodomik kent planlarına sahip antik şehirlerle karşılaştırılması tapınağın konumuyla ilgili olarak bize ipuçları sunabilecektir. Nikaia kent planına benzer şekilde Colonia Claudia Ara Agrippinessium (Köln) gibi Hippodamik plana sahip kentler forum ve praetorium gibi önemli kamu yapılarının yer aldığı birbirini dik kesen iki ana caddeye sahiptir (Avc1, 2005: 90). Bu benzer plan yapisı Nikaia kentinde de karşımıza çıkmaktadır. Buna göre Nikaia'daki Roma Dönemi kent merkezindeki bu tip forum ve gymnasyon gibi kentin önemli sivil yapılarının yer aldığı aksta kentin kurucu ve baş tanrısı Dionysos için bir tapınak olduğu düşünülebilir (Şahin, Mert, 2011: 176). İznik'te tarihsel süreç içerisinde Hristiyanlık Dönemi'nde inşa edilen birçok dini yapının eski tapınakların temelleri üzerine kurulduğu düşünülmektedir (Şahin, Mert, 2011: 174). Bu konuda Semavi Eyice'nin Aya Sofya Kilisesi'nin altında bir tapınağın varlığından

2 Güçlü 2007: 48, “29 İmparator Hadrianus için Atıf Yazıt 123”; (Ed.) S. Şahin, I.V. Nikaia nr. 29. 
bahsettiği görüşü de (Eyice, 2005: 331) dikkate alınırsa muhtelif tapınağın lokasyonu olasılıkla bu kilisenin temellerindedir (Resim 18).

Nikaia'da tapınım gören ve adına inşa edildiği düşünülen bir başka kült ise Apollun'un oğlu sağlık ve şifa tanrısı Asklepios'tur. Nikaia kentinde epigrafik belgelerle de kültünün varlığı kanitlanan Asklepios sikke tasvirlerinde genellikle atribüleri olan yılan ve asası ile temsil edilmiştir (Boyana, 1997: 223). Sikke tasvirinde tetrastylos tapınağın öncephesinde, geniş bırakılan orta sütunlar arasında bir kült figürü bulunmaktadır (Resim 19). Figür ayakta ve sola dönük, sağ elinde bir yılanın dolandığı asa tutmaktadır. Üçgen alınlık iki yılan ile süslenmiş ve köşelerinde akroterler belirtilmiştir. Tapınağın çevresindeki $C \Omega$ THP (Kurtarıcı) lejandı ve yılan betimleri, yapının Asklepios tapınağı olduğuna işaret etmektedir (Bosch, 1935: 128). Bu noktada özellikle Pers savaşlarında orduda vuku bulan veba salgını sebebiyle özellikle M. Aurelius sikkelerinde iyileştirici bir tanrı olarak Asklepios kültü tasvirlere işlenmiş olmalıdır (Erol, Özdizbay, 2011: 151). Bu nedenle M. Aurelius onun kurtarıcı bir tanrı olduğuna hükmetmiş ve kent halkının katkıları ile onun adına bir tapınak inşa ettirmiş olmalıdır. Yapının lokasyonu hakkında ise henüz kesin birşey söylemek şimdilik olanaksız olsa da bu muhtelif yapının bugün İznik'te yer alan Koimesis Kilisesi'nin yaklaşık 50 metre doğusunda bulunan Böcek Ayazması ile ilintili olduğu düşünülmektedir. Ayazma yapılarının Hristiyanlık Dönemi'nde kutsal su veya şifa verici bir merkez olarak kullanıldığı ve her birinin mutlaka bir dini yapı ile ilişkili olduğu bilinmektedir (İhtiyar, 2020: 611). Bu durum tanrıça Asklepios kültü ile bağlantılı olarak antik dönemde de burasının sağlık merkezi olarak Asklepion'un bir bölümünü oluşturduğunu akla getirmektedir (Resim 18).

Nikaia'da sikke betimlerine göre tanrıça Tykhe gibi kent kavramını tanrı olarak kişiselleştiren kültlere ait tapınaklar da bulunmaktadır. Tykhe, genellikle her yerde rastlanan ve karakteristik özelliklerine göre talih yönlendiricisi, kent tanrıçası veya talih tanrıçası olarak tanımlanmaktadır (Bosch, 1935: 156). Roma Dönemi'ndeki ismi ise Fortuna'dır (Boyana, 1997: 82). Tykhe, atribülerinden bereket boynuzu (Cornucopia), kalathos ya da devletlerin kaderini yönlendiren tanrıça olarak bir gemi dümeni ile görünmektedir (Matheson, 1994: 20-22). Nikaia'da söz konusnu tanrıça mimari sikkelerde genellikle oktastylos tapınak içerisinde gösterilmiştir. Tykhe tapınağının en çok resmedildiği dönem İmparator Caracalla zamanıdır. Caracalla'nın 212 
yılında doğu eyaletlerine yaptığı ziyareti anısına Nikaia kenti için tanrıça Tykhe adına bir tapınak yaptırılmasına yardımda bulunduğu bilinmektedir (Şahin, 2009: 16). Bu Caracalla sikkelerinden birinde hexastylos tapınak sol profilden perspektif açıyla verilmiştir (Resim 20). Tapınağın uzun tarafında yedi sütun sayılabilmektedir. Alınlıkta iki boynuz arasında üst üste iki clipeus yer alır. Orta sütunlar arasında ayakta sola dönmüş şekilde betimlenen kült heykeli başında taşıdığı kalathos ve sol elinde sceptre tutmaktadır. Tykhe sağ elinde ise bir Nike tutmakta ve bunu önündeki sunağa doğru uzatmaktadır. Burada açıkça bir libasyon sahnesi resmedilmiştir. Söz konusu tanrıçaya ait tapınak bir Salolina sikkesinde ise bu kez cepheden resmedilmiştir (Resim 21). Salonina sikkesinde Tykhe'nin celladaki duruş vaziyeti benzerdir; sola bakar şekilde ayakta betimlenen Tykhe elinde dümen ve bereket boynuzu tutmaktadır. Sonuç olarak sikke tasvirlerine göre tanrıca Tykhe' nin Gallienus'un eşi Salonina serisine göre tanrıçanın MS 3. yüzyılın üçüncü çeyreğine kadar kentte tapınım gördüğü anlaşılmaktadır. Tasvirlerde temsil edilen tanrıça Tykhe, Nikaia kentinin kişisel bir şekli yani personifikasyonu olduğu da kabul edilebilir.

\subsection{Nikomedeia / Kocaeli}

Bithynia Bölgesi'nin başkenti olan Nikomedeia kenti, Bithynia Krallarından I. Nikomedes tarafından Propontis'in kuzeydoğu ucunda "Sinus Astacenus" denilen bir yerde kurulmuştur (Strab. XII 4.2). I. Nikomedes, Zipoetum kenti yerine burasını başkent ilan etmiş ve şehre kendi adına ithafen Nikomedeia adını vermiştir (Mem. Frag. 20). Romalı asker ve devlet adamı olan Pompeius Magnus'un bölgedeki düzenlemelerinden sonra Bithynia Eyaleti'nin başkenti olarak Nikomedeia kenti Bithynia Koinonu'nun (Bithynia Birliği) merkezi olmuştur. Bu başkentlik süreci ile Nikomedeia şehir mimarisi anlamında daha çok gelişme göstermiş ve yapılan bu kamusal ve dini yapılar sikke arka yüzlerinde sıkça göserilmiştir. Nikomedeia sikkelerinde en çok dikkat çeken mimari tipler kent planı hakkında oldukça fikir verici durumda olan imparatorlara adanmış tapınakları gösteren neokorosluk sikkeleridir.

\subsection{1. İmparatorluk Tapınağı Betimleri}

İmparatorluık tapınaklarını gösteren sikkeler genellikle "Neokoros" ünvanıyla onurlandırılan kent sikkelerinde bulunmaktadır. Neokoros, 
“Tapınak Muhafızlığı” anlamına gelmekle birlikte Küçük Asya'da İÖ 1. yüzyılda Augustus'tan sonra yayılan imparatorluk kültüyle alakalı olarak imparator tapınağına sahip kentlere ünvan olarak verilmekteydi (Merkelbach, 1978: 287). C. Marek'e göre Bithynia'daki en eski arkeolojik veriler MÖ $29^{\prime}$ da Augustus'un onuruna bir kült başlattıklarını vurgulamaktadır (Marek, 2009: 40). Bu kapsamda Augustus tarafından Nikomedeia'ya tapınak inşa etme hakkı verilerek kente Neokoros statüsü verilmiştir (Dion Cass. LI 20,7-8). Sonrasında Nikomedeia kenti imparatorluk çağı boyunca üç kez Neokorosluk ünvanı ile onurlandırılmıştır (Arslan, 1996: 107). Kentin genel planı hakkında fikir sahibi olabileceğimiz seriler de söz konusu neokorosluk sikkeleri üzerinde teşhir edilmişlerdir. Resim 22'deki plan şeması üzerine yerleştirilen sikkeler bu konuya açıklık getirecek arka yüz betimlerini teşkil etmektedir. Geta adına darbedilen bronz seride ortada Demeter'in heykelini taşıyan bir sütun ve her iki yanında hexastylos karşılıklı olarak köşeleme yerleştirilmiştir (RG, 1910: 550, No.263 Pl.XCV/10). Burada yer alan Demeter sütunu olasılıkla Nikomedeia formunun bir parçasını oluşturmaktaydı. Nikomedeia'daki Neokorosluk sikkelerinin bir başka teması imparator tapınaklarıla birlikte gösterilen liman betimleridir. Septimius Severus sikkesindeki tasvirde; altta kürekçileriyle birlikte bir tekne resmedilmiştir. Üstte ise iki oktastylos tapınak ayn hat üzerinde, uzaklık algısı oluşturmak amaciyla küçültülerek betimlenmiştir (RG, 1910: 537 No.165). Burada limanın kendisi gösterilmese de neokor tapınaklarının limana yakın bir mevkide olduğu anlaşılmaktadır (Donaldson, 1965: 137; Güney, 2013: 1473). Bahsi geçen ikinci neokorosluk sikkelerinden anlaşıldığı üzre tasvirlerde imparator tapınakları ile birlikte kentin ana tanrıçası Demeter kültü yüceltilmiş, fakat Nikomedeia forumu ile ilgili doğrudan bağlantı kurulabilecek bir başka ayrıntıya yer verilmemiştir. Ancak MS 2. yüzyılda basılan üçüncü neokorosluk sikkelerinde tasvir edilen imparatorluk tapınakları bu görüşün dişındadır. Zira kentin üçüncü kez neokorosluk ünvanıyla onurlandırıldığı Elagabalus Dönemi'nde darbedilen TPICNESKOPQN lejantlı sikkeler esasen Nikomedeia formunun asıl durmuna da işaret etmekteydi. Bu sikkelerin arka yüzlerinde üç tapınak figürüne de aynı anda yer verilmiştir. Karşılıklı duran imparator tapınakları perspektif olarak gösterilirken Demeter tapınağı bu ikisi arasında cepheden tasvir edilmiştir (SNG, 1957: Taf.26/859). Orta kısımda bir yılanın sarıldığı yuvarlak sunak ve bunun her iki 
yanında imparator tapınakları yer almaktadır. Sunaktaki yılan, olasılıkla kentteki Asklepius kültüyle ilişkilidir (Ruge, 1936: 485).

Antiochialı antik yazar Libanius, tapınakların bulunduğu forumun kıyı kenarında olmayıp kentin yamacına kurulduğundan ve Nikomedeia limanı ile forum arasında sütunlu bir caddenin bulunduğundan bahsetmiştir (Libanius, Orationes LXI 7). C. Bosch ise Libanius'un aktardığı bilgileri destekler nitelikte veriler sunmuş ve Nikomedeia'da tapınakların ve diğer kamusal binaların bulunduğu forum ile liman arasındaki bağlantının bir sütunlu cadde ile sağlandığını belirtmiştir (Bosch, 1937: 31). Bununla ilgili olarak, özellikle Geta ve Elagabalus döneminlerinde basılan sikke betimlerinden yola çıkarak Nikomedeia forumunun olası bir planını çizmiştir. Plana göre Nikomedeia'da tapınakların ve diğer kamusal binaların bulunduğu forum ile liman arasındaki bağlantı, bir sütunlu cadde ile sağlanmaktadır. Ayrıca üzerinde Demeter heykeli ile süslenmiş anitsal sütunun bulunduğu forum burada şehrin merkezinde bulunmakta ve bunun her iki yanında imparator tapınakları yer almaktadır (Bosch, 1935: 249). Sonradan imparator tapınağına dönüştürülen Demeter Tapınağı ise merkezdedir. Ancak sonuç olarak söz konusu sikke tasvirlerinden yola çıkılarak hazırlanan bu planda liman ile forum arasında plansal bir ilişkiden bahsedilebilse de iki yapı arasındaki unsuru biribirine bağlayan arkeolojik veriler henüz keşfedilemediği için sütunlu caddenin varlığı henüz tespit edilebilmiş değildir.

\subsection{Prusias ad Hypium / Konuralp}

Prusias ad Hypium günümüzde Düzce İli, Konuralp İlçesi mevkiindedir (Resim 1). İlk olarak Kieros olarak bilinen kent, Hypios (Melen) Çayı üzerinde kurulduğu düşünülmektedir (Karakuş, 2017: 31). Kentin ilk kuruluşu hakkında bilgi edinilebilen en önemli kaynaklardan birisi olan Memnon'a göre, ilk olarak Bithynia Kralı Zipoetes tarafından ele geçirilmiş, ancak MÖ 280 yılında I. Nikomedes bu kenti I. Antiochos ile yaptığı savaşta kendisini destekleyen Herakleia'ya bırakmıştır (Mem. X 2; IX 4). Sonrasında I. Prusias (MÖ 283-183) tarafından şehir tekrar ele geçirilmiş ve eskisine göre burasını daha bayındır hale getirerek şehri kendi adıyla (Prusias ad Hypium) yeniden kurmuştur (Umar, 2004: 119). Kente ait sikkeler en erken İmparator Vespasianus Dönemi'nden başlar ve Gallienus Dönemine kadar devam eder. Bu sikkelerde kentin adı ПРОYCIESN ПРОС 
YП $\Omega$ I (Prusias Pros Hypios) olarak yazılmıştır (RG, 1912: 603-604). Roma Dönemi'nde mimari anlamda yeniden biçimlendirilen kentte sivil ve askeri birçok yapı bulunmaktadır. Bunlardan tapınaklar ve sur kapıları sikke betimlerine de yansımıştır.

\subsubsection{Tapınak Betimi}

Prusias ad Hypium kentinde kalıntıları günümüze kadar gelebilen bir tapınak yapısı bulunmamasına karşın bu kentte birden fazla tapınağın olduğu düşünülmektedir (Zeyrek, Çelik, 2005: 40). Bu tapınaklardan biri Antoninus Pius (MS 138-161) adına darbedilen bir bronz sikkede resmedilmiştir. Söz konusu sikkenin arka yüzünde dört sütunlu bir tapınak öncephesi tasvir edilmiştir (Resim 23). Tapınak tasvirinde geniş bırakılan iç sütunlar arasında bir kült heykeli; oturur vaziyette ve sağa dönük şekilde, sol elinde sceptre, sağ elinde patera tutuyor. M. Jessop Price, Prusias ad Hypios'un kontrmarklarını incelediği makalesinde, KAПET $\Omega \Lambda$ ION $\Sigma$ EBA $\Sigma T O N$ lejantlı bu sikkenin kentin baş tanrısı olan Zeus ile bağlantılı olduğunu ileri sürmüştür (Price, 1967: 37-39). Kült heykelinin duruş özellikleri ve Price'nin yaptığ 1 yorum dikkate alınırsa tapınak içerisindeki bu figürün Zeus'a ait olduğu kuvvetle muhtemeldir.

\subsubsection{Kent Kapısı Betimleri}

Prusias ad Hypium kentinin güneyindeki dağın eteklerinde Bithynia Krallığ1 Dönemi'nden kalma sur kalıntıları olduğu bilinmektedir. Kamil Doğancı'ya göre kentte MS 3. yüzyıla tarihlenen bazı yazıtlar Goth saldırılarına karşı kent surlarının güçlendirildiğine dikkat çekmektedir (Doğanc1, 2007: 142). Gallienus Dönemi darbedilen bir sikkenin arka yüzünde görülen şehir surlarına ait çift kuleli kapılar buna işaret ediyor olmalıdır (Resim 24-25). Tasvirde sur yapısının içine doğru açılmış olan esas ana giriş kapısı ortaya yerleştirilmiştir. Her iki yanda koni şeklindeki çatı formuna sahip burçlar ve altında bunlara ait kapılar görülmektedir. Kapıların her üçü de yarım daire bir kemerle sonlandırılmıştır. Sikkede tasviri görülen kapının kent surlarına ait hangi kapı olduğu bilinmemektedir. Ancak Gallienus Dönemine tarihlenen bu yapının tıpkı Nikaia surlarında olduğu gibi imparatorluğun MS 3. yüzyılda Goth istilalarından sonra yapılan sur tahkimatlarına işaret ettiği düşünülebilir. 


\begin{abstract}
3.7. Herakleia Pontika / Zonguldak-Ereğli
Antik Çağda Bithynia Bölgesi'nin kuzeydoğusunda yer alan Herakleia Pontika kenti, antik yazarlar tarafından Megaralılar ve Boiotialılar tarafından MÖ 6 . yüzyılda kolonize edildiği söylenmektedir (Plin. Nat. VI.4; Strab. XII. 3.4). Lokasyonu günümüzdeki Karadeniz Ereğlisi olan kent, adını Karadeniz'deki Herakles'in kenti anlamına gelen Herakleia Pontika'dan almaktadır. MÖ 4. yüzyılda kurduğu tiranlığa dayalı, güçlü idari yapısıyla kent, Roma Dönemine kadar bölgenin en önemli siyasi otoritelerinden biri konumuna ulaşmıştır (Öztürk, 2013a: 507). MÖ 1. yüzyıldan sonra

Roma hâkimiyetine giren Herakleia Pontika kenti, MÖ 64 yılında General Pompeius tarafından oluşturulan Bithynia et Pontus Eyaletine dâhil edilmiştir (Strab. XII 3.6). Herakleia'nın Roma egemenliğine girmesiyle Romalı kolonistler bölgeye gelmiş, imar faaliyetleri başlatılmış ve şehre yeni mimari yapılar kazandırılmıştır. $\mathrm{Bu}$ durum kent adına darbedilen sikkelere de yansımış ve bu kapsamda sikkelerde fener kulesi ve tiyatro gibi mimari tipler yer almıştır.
\end{abstract}

\title{
3.7.1. Fener Kulesi Betimleri
}

İmparator Geta ve Gallienus adına darbedilen sikkelerin arka yüzlerinde çok katlı ışıklandırma kuleleri görülmektedir (Resim 26). Geta serisinde; tepesinde bir ateş yanan altı katlı fener kulesi bulunmaktadır (Resim 26a). Kuleye ait katların üzerinde bloklara işaret eden yatay ve dikey çizgiler yer almaktadır. Gallienus serisinde ise üç katlı kule biçimindeki yapı, hacim ve boy olarak daha yüksekçe tasarlanmıştır (Resim 26b). İkinci ve üçüncü kata göre daha geniş olan alt katta yarım daire kemerli bir giriş kapısı bulunmaktadır. Genel olarak bakıldığında epigrafik ve nümizmatik kaynaklar, sikke tasvirlerinde gösterilen kule hakkında tamamlayıcı bir bilgi vermezler. Ancak Herakleia'nın Roma İmparatorluğu Dönemi'nde önemli bir limana sahip olması dikkate alındığında bu kentte böyle bir yapının mevcudiyeti kabul edilebilir bir görüştür.

\subsubsection{Tiyatro Betimi}

Herakleia Pontika sikkelerinde tasvir edilen diğer bir mimari yapı tiyatro veya stadion diyebileceğimiz yapılardır. Bununla ilgili 
İmparator III. Gordianus zamanında basılmış olan seriler, içi seyirciyle dolu bu yapıyı temsil etmektedirler (Resim 27). Sikke önyüzünde kentin baştanrısı olarak kabul edilen Herakles'in diademli ve sakallı büstü görülmektedir. Omzunda ise sikke tasvirlerinde sıkça görülen atribülerinden bir gürz taşımaktadır. Arka yüzde yer alan tiyatro tasvirinde ise; bina diş cephesinden görülür bir şekilde tasarlanmışır. Donaldson, orta kısımda herhangi bir spina yapısı bulunmadığ tiyatro olabileceği üzerinde durmaktadır (Donaldson, 1965: 283). Să̆ tarafta tiyatro binasının kapısı görülmektedir. Yuvarlak biçimli orkestranın içine doğru açılan ve ilerleyen tapınak şeklindeki bina olasılıkla skene vazifesi görmektedir. Skene ve orkestra binasının önünde, karşılıklı duran iki çıplak figür bulunmaktadır. Sol tarafta ayakta duran figür, sağ elini başının üzerine doğru kaldırarak diğer figürü selamlamakta ve elinde yaya benzer bir obje tutmaktadır. Sağ taraftaki figür ise oturur halde ve sağ elinde olasilıkla bir nesne tutmaktadır. Recueil Général'de oturur vaziyetteki figürün Dionysos veya Herakles olabileceği ve elinde tuttuğu nesnenin de kantharos olabileceği yönünde açılama yapılmıştır (RG, 1908: 357, No. 76). Yunan dünyasında kültü oldukça yaygın olan Herakles adına bu kentte dâhil pek çok agon düzenlendiğini (Erol, Özdizbay, 2011: 246) gözönüne alırsak figürün Herakles olduğu akla yatkın görünmektedir. Ancak bu iki figürün kimliklerinin mutlak olarak teşhis edilemese de bu tip agonistik tasvirlerin Herakles onuruna düzenlenen oyunlara işaret ettiği düşünülebilir.

\subsection{Bithynion-Claudiopolis / Eskihisar}

Eyaletin doğusundaki Bithynion kenti bugünkü Bolu ili Eskihisar mevkiinde yer almaktadır (Resim 1). D. Magie kent hakkında "Hypius nehrinin doğu havzasını oluşturan dağ sırası boyunca uzanandığını ve Pontus'a giden ana yol üzerinde olduğunun söylemektedir (Magie, 1950: 307). Strabon'un kendi eserinde verdiği bilgiler de Magia'nin kent hakkında söylediklerini teyit etmektedir (Strab. XII. 4.7). Adını Bithynia Krallığı'ndan alan bu kent, I. Nikomedes tarafından kurulmuştur (Jones, 1937: 151). Roma Çağı'nda İmparator Claudius tarafından kentin ismi Claudiopolis olarak değiştirilmiştir (HarisRyde 1980: 880). Bithynion kentinde Roma Dönemi'nde darbedilen sikkelerde mimari tasvir olarak oktastylos tapınaklar hâkimdir. 


\subsubsection{Tapınak Betimleri}

Cephesi sekiz sütunlu tapınak tasviri ilk olarak Hadrianus tarafından, gözdesi Antinous adına darbedilen bir sikkede görülmektedir (Resim 28). İmparator Hadrianus, gözdesi Antinous'un doğum yeri olmasi nedeniyle kente heykelini diktirmiş, sikkelerinde ona da yer vermiştir.

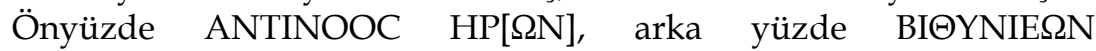
A $\triangle$ PIAN $\Omega N$ lejandı Antinous'un portresini çevrelerken, arka yüzde ise oktasytlos tapınak cephesine yer verilmiştir (RG, 1908: Pl. XLI/209). Antinous'a ait portrelerin sikkelerde görülmesi onun tanrı yerine konulduğunun nümizmatik kanıtlarından biridir (Boyana, 1997: 339) Septimius Severus serilerine göre ise oktastylos tapınak cephesinin üç krepisli bir stylobat üzerinde ion sütunları ile birlikte yükseldiği anlaşılmaktadır (Resim 29). Oktastylos tapınak tasvirlerinin niteliği hakkında fikir oluşturacak sikkeler ise Alexander Severus adına darbedilmişlerdir (Resim 30). Sikke tasvirindeki tapınağın iç kısımda; ayakta bir erkek figürü sağ elinde mızrak, sol elinde hançer tuttuğu görülmektedir. Başında ise tacı bulunmaktadır. Figür olasılıkla bir İmparator'a aittir. Bu figürün hangi imparatora ait olduğu tartışma konusudur. Bu konuda Bithynion kentinin İmparator Hadrianus zamanında Antinous nedeniyle büyük bir üne sahip olduğu ve bu nedenle "Hadriane" unvanı aldığı gözönüne alınmalıdır (Haris-Ryde, 1980: 895). Aynı zamanda Bithynion kentinde Antinous'un İmparator Hadrianus tarafından kurulan bir tapınağ 1 ve kültü olduğu düşünülmektedir (Price, 2004: 433). Bu nedenle sikke arka yüzlerinde tasvir edilen tapınak içindeki kült heykelinin $\mathrm{A} \triangle \mathrm{PIAN} \Omega N$ lejandı da göz önüne alındığında İmparator Hadrian'a ait olduğu kuvvetle muhtemeldir. Sikkeler, tapınağın içinde mizrağıyla duran bir imparatoru gösterdiğine göre bu tasvirler olasılıkla Bithynion kentindeki bir imparator tapınağının varlığını göstermektedir (Price, 2004: 433).

\subsection{Iuliopolis / Nallihan}

Iuliopolis kenti Bithynia'nın iç kısmında, eyaletin güney sınırında Nikaia'ya giden önemli bir yolun üzerinde kurulmuştur (Haris-Ryde, 1980: 877). Kent lokasyonu, bugünkü Ankara ili Beypazarı yakınlarındaki Nallıhan'ın güney kesimindedir (Wilson, 1961: 139). Aynı zamanda güney kısımda Bithynia Eyaleti'nin Galatia ile olan sınırın belirlemektedir (Resim 1). Kentin doğudaki sınırı tartışmalı olmakla birlikte Hierus (Aladağ Çayı) ile sinırlandığı 
düşünülmektedir ki, Yaşlı Plinius'a göre burası aynı zamanda Bithynia topraklarının doğudaki en son sınırı idi (Plin. Nat. V 149). Genç Plinius, Iuliopolis'i Bithynia kentleri arasında göstermiştir (Plin. Epist. $X$ 78). Iuliopolis kenti, İmparatorluğun ilk yıllarında Augustus'un ölümünden sonra Bithynia Eyaletine katılmıştır (RG, 1908: 384). Iuliopolis kenti, Roma İmparatorluk Çağı'nda, İmparator Vespasianus'tan Gallienus'a kadar olan dönemde bronz sikkeler basmıştır. Kentin adı sikkeler üzerinde IOY $\Lambda$ IOחOAE I T $\Omega N$ ve I O Y

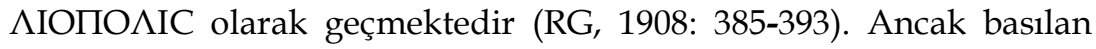
sikkelerde yer alan arka yüz tasvirlerinde herhangi bir imparator tapınağı resmedilmemiştir. Bunun yerine şehir tanrıçası Tykhe (Fortuna) betimli öncephesi tetrastylos tapınak tasvirleri tercih edilmiştir.

\subsubsection{Tapınak Betimi}

Iuliopolis sikkelerine ait tek mimari tasvir İmparator Geta adına darbedilmiş bir bronzda görülmektedir (Resim 31). IOVLIO-POLEIT$\Omega N$ lejantlı sikkenin arka yüzünde iki basamaklı bir podyum üzerinde cephesi dört sütunlu bir tapınak tasviri yer almaktadır. Tapınak alınlığı bir halka ile süslenmiştir. Genişçe bırakılan orta sütun aralığında tapınağa ait kült heykeli bulunmaktadır. Başında sur çelengi taşıyan giyimli tanrıça sol elinde bereket boynuzu ve sağ elinde başak demeti tutmaktadır. Taşıdığı atribülerinden dolayı kült heykelinin tanrıça Tykhe'ye ait olduğu anlaşılmaktadır. Tapınak ile ilgili henüz arkeolojik bir veri bulunmadığından yapının konumu hakkında herhangi bir yorum yapılamamaktadır.

\subsection{Tios / Filyos (Hisarönü)}

Günümüzde Zonguldak iline bağlı Filyos/Hisarönü'ne konuşlandırılan Tios/Tieon antik kenti (Resim 1), MÖ 7. yüzyılda Tios adlı bir rahibin öncülüğünde Miletoslular tarafından kurulmuş bir koloni şehridir (Marek, 1993: 16; Öztürk, 2008: 64). İskender'in generallerinden Lysimachos'un ölümünün ardından MÖ 3. yüzyılda Zipoetes tarafından Bithynia Krallı̆̆g'na ilhâk edilen Tios kenti, (Mem. Hist. XVI, 35) MÖ 64 yılında Pompeius Magnus yapmış olduğu idâri düzenleme ile Pontus et Bithynia Eyaleti'ne dâhil etmiştir (Strab.XII.3.6). Tios kenti Roma Dönemi'nde İmparator Domitianus'dan Gallienus'a kadar sikke darbetmiştir (Öztürk 2013b: 488). Şehrin adı sikkeler üzerinde TIAON veya TIAO $\Sigma$ olarak 
görülmektedir (RG, 1912: 615). Tios kentinde görülebilen yapılar arasında Roma ve Bizans Dönemi'ne ait, Bizans kilisesi ve Antik limana ait kalıntıların yanı sıra bir Roma Tapınağı bulunmaktadır (Yıldırım, 2017: 207). Kentte süren arkeolojik kazı çalışmaları sonucu keşfedilen söz konusu Roma Tapınağı' na 1şık tutacak mimari betimli sikke serileri mevcuttur.

\subsubsection{Tapınak Betimi}

Tios'taki Roma tapınağına 1şık tutacak en önemli nümizmatik delil bir Severus Alexander bronz sikkesinde yer almaktadır (Resim 32). Bu sikkenin arka yüzünde kült heykeli ile birlikte öncephesi iki sütunlu bir tapınak tasvir edilmiştir. Ortada yer alan kült heykeline yer açmak için köşe sütunları hariç cephedeki bütün sütunlar kaldırılmıştır. Entablatürde alınlık belirtilmemiş, alt kenarın kaldırılması suretiyle alınlık boşluğunun cellaya ilâvesi tercih edilmiştir. Kült heykeli giyimli ve cepheden, ayakta, başı sola dönüktür. Sol elinde asa ve sağ elinde bir patera tutmaktadır. Solda ayaklarının yanında ise kanatları ile birlikte görülen bir kartal figürü durmaktadır. Kült heykelinin duruş özellikleri ve kullandığı atribüleri dikkate alındığında bunun bir Zeus heykeli olduğu anlaşılmaktadır. Bu antik kentte yapılan araştırmalara göre sikkedeki tapınağın lokasyonuna işık tutacak en önemli deliller antik kentin "Yukarı Akropolis" olarak adlandırılan mevkiisinde bulunmaktadır (Yıldırım, 2017: 215). Burada Geç Arkaik Dönem'den itibaren askeri ve sivil anlamda yapılaşma yoğunlaşmıs, ancak gerek arkeolojik gerekse mimari veriler 1şı̆̆ında Klasik ve Helenistik Dönemle birlikte yapılaşma karakteri değişerek daha çok dini anlamda bir mimari organizasyon görülmeye başlamıştır (Yıldırım, 2017: 216). Burada karşılaşılan en önemli yapı MS 3. yüzyılın ilk yarısına tarihlendiği düşünülen Zeus Tapınağı'dır. Yapı kalıntılarına göre 6x11 sütunlu bir peripteros plana sahip olması muhtemel bu yapıdan günümüze sadece podyum kaplamasına ait bir bölüm ve harçlı moloz taşlardan oluşmuş temel dolgusu korunmuştur (Baran vd., 2015: 137). Arkeolojik veriler göz önüne alındığında bu yapı kalıntısı S. Alexander sikkesindeki Zeus ile birlikte tasvir edilen tapınağ 1 temsil ettiği kuvvetle muhtemeldir. Tios kentinde özellikle akropoliste yapılacak olan kazıların sürmesiyle birlikte tapınak ile ilgili daha ayrıntılı bilgiler elde etmek mümkün olacaktır. 


\subsection{Kreteia-Flaviopolis / Gerede}

Kreteia kenti bugünkü Bolu iline bağlı Gerede ilçesi sınırları içerisindedir (Resim 1). Kent Kral Ziaelas tarafından Bithynia topraklarına katılmıs Roma İmparatorluk Çağı'nda ise Vespasianus tarafından kendi hanedan adıyla Flaviopolis olarak yeniden kurulmuştur (Haris- Ryde, 1980: 880). Roma Çağı'ndaki ilk sikkeler Antoninus Pius Dönemi'nde basılmaya başlanmış ve İmparator Gallienus'a kadar devam etmiştir (RG, 1908: 333 No.1-4). Kreteia kentindeki sikkelerde mimari tipler olarak cephesi dört sütunlu tapınaklar hâkimdir.

\subsubsection{Tapınak Betimleri}

Tapınak tasvirlerinin her ikisi de Iulia Domna adına darbedilen bronzlarda görülmektedir. Illk sikke tasvirinde tetrastylos bir tapınak cephesi kült heykeli ile birlikte tasvir edilmiştir (Resim 33). Tapınak içindeki kült heykeli oturur vaziyette ve cepheden betimlenmiştir. Kült heykeli sağ elinde bir patera ve sol elinde bir sceptre tutmaktadır. Iulia Domna adına darbedilen bir başka seri de ise aynı tetrastylos tapınak bu defa sol perspektiften gösterilmiştir (Resim 34). Tapınak tasvirinde oturur vaziyetteki kült bir önceki sikke tasvirinde olduğu gibi sol elinde sceptre, sağ elinde ise patera tutmaktadır. $\mathrm{Bu}$ özellikleriyle kült figürünün Zeus'a ait olduğu anlaşılmaktadır. Tapınağın uzun tarafı görsel açıdan sadeleştirilmiş olduğundan bu kısımda kaç sütun bulunduğu belirgin değildir. Lokasyonu henüz belli olmasa da söz konusu sikke tasvirlerine göre Kreteia kentinde Zeus'a adanmış olduğu düşünülen bir tapınağın varlığından bahsedilebilir.

\section{DEĞERLENDİRME VE SONUÇ}

Sonuç olarak makalemizde Roma Dönemi'nde Bithynia Eyaleti'nde yer alan mimari anlamda sikke tiplerine sahip toplam 11 kent incelenmiştir. Sikke tasvirlerine göre Bithynia'daki Roma Dönemi antik kentlerinde tapınaklar, circus, tiyatro, amphitiyatro, thermae, liman kompleksi, fener kulesi ve iki katlı anitsal yapılar ile imar edildiği anlaşılmaktadır. Buna göre Bithynia'da MS 1. yüzyılda başlayan yapı faaliyetleri MS 3. yüzyılın sonuna kadar devam etmiş, bu yapılar Roma İmparatorluğu'nun finansal desteği ile birer 
ihtiyaçtan öte siyasal propaganda amacı taşımıştır. MS 3. yüzyılın sonuna doğru artan Goth saldırılarına karşı savunma amaçlı yapıldığı anlaşılan kent surları ve şehir kapıları şehirlerde gerçekleştirilen askeri tahkimatlara dikkat çekmektedir. Bununla birlikte söz konusu kentlere ait yapıların depremler, yangınlar ve istilalar sonucunda tahrip oldukları antik metinler aracılığıyla anlaşılmaktadır. Bundan dolayı Roma Dönemi'nde inşa edilen birçok mimari yapının lokasyonu henüz tespit edilememesine rağmen bununla ilgili bazı fikirler öne sürülmüştür. $\mathrm{Bu}$ anlamda Helenistik ve Roma Dönemlerinde inşa edilen birçok pagan tapınağın Hristiyanlık sonrası kilise ve bazilikaya dönüştürüldüğü göz önüne alınarak tapınak yapılarının lokasyonu kentteki bazı kiliselerin temellerinde aranması gerektiği hipotez olarak öne sürülmüştür. Kent sikkelerinde mimari tasvirler halk arasında dolaşımı en fazla olan bronz serilerde görülmektedir. Bunun nedeni olasılıkla halkın geniş kesimlerine pratik ve hızlı ulaşım sağlayarak merkez Roma'nın egemenliğini hissettirmekti. Sikke betimlerine göre Apollon, Asklepios, Demeter, Dionysos ve Tykhe (Fortuna) gibi tanrı ve tanrıçalar imparatorluk süresi boyunca tapınım görmüş ve bunlar sikke tasvirlerinde anıtsal yapıtlar içerisinde gösterilerek kutsallaştırılmıştır. Bunların yanı sıra kentlerde düzenlenen agon oyunlarını temsil eden mimari betimli sikkeler de bulunmaktadır. Bunlardan özellikle Nikaia kentindeki Severeia oyunları ve Herakleia Pontika kentinde Herakles adına düzenlenen bayram oyunlarını temsil etmektedir. Bithynia'daki antik kentlerde kazısı yapılmış veya tanıtılmış olan mimari yapıtlar, esasen ortak sonuçlar çıkarmak için henüz yetersizdirler. Henüz bilinmeyen birçok mimari sikke tipi de olabilir. Bu konuda eksik kalmış birçok detay, yeni kazılar ve araştırmalar sayesinde elde edilen veriler ile sonradan tamamlanacaktır. Bununla birlikte, antik kentlerde arkeolojik yüzey araştırmalarının yapılması ve gerekli görülen yerlerde arkeolojik kazı ve sondajların yapılması da sikke tasvirlerinde yer alan kayıp yapıların araştırılması konusunda büyük katkı sağlayacaktır. Böylelikle geçmişin muazzam başyapıtlarının küçük görsellerini gösteren mimari betimli sikkeler Bithynia'daki antik yapılara bakış açılarımızı genişletmektedir ve genişletmeye de devam edeceklerdir. 


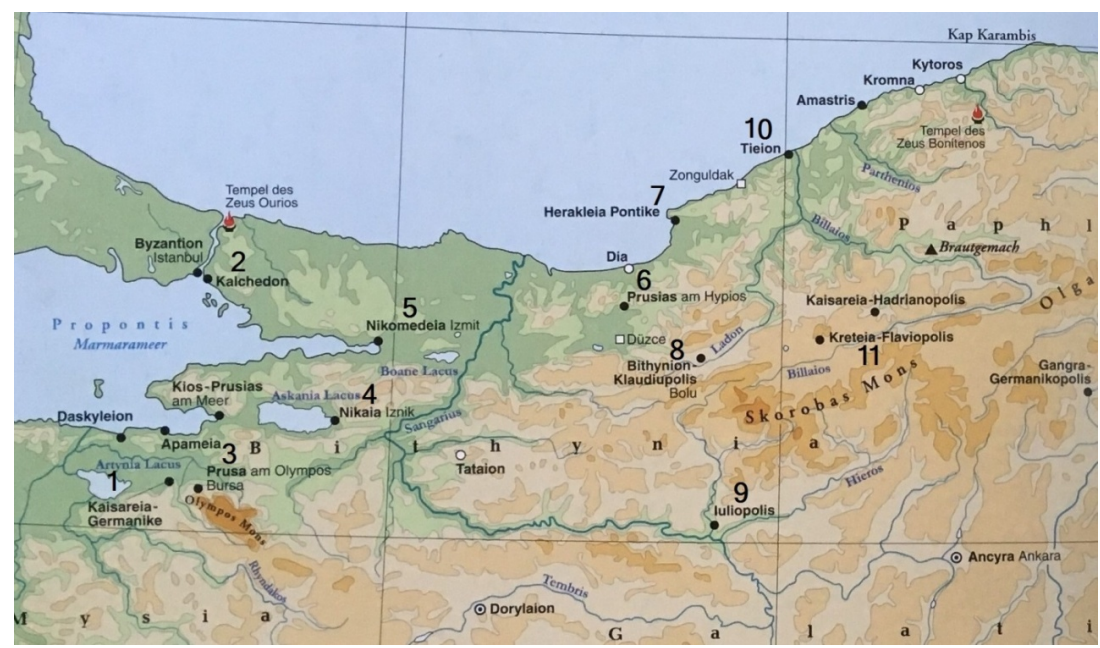

(Kaynak: https://rpc.ashmus.ox.ac.uk/maps/1.2).

Resim 1-Bithynia Bölgesi'nde Mimari Sikke Basan Antik Kentler.

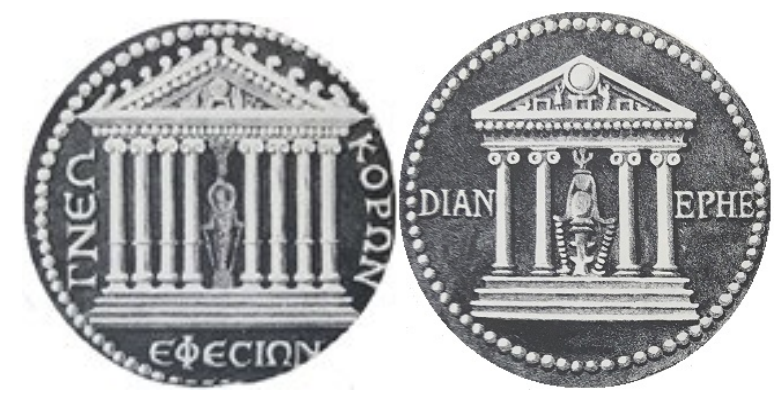

(Kaynak: Donaldson, 1859: No. 6-24).

Resim 2-Daina Tapınağı Oktastil ve Tetrastylos Karşılaştırma Örnekleri. 


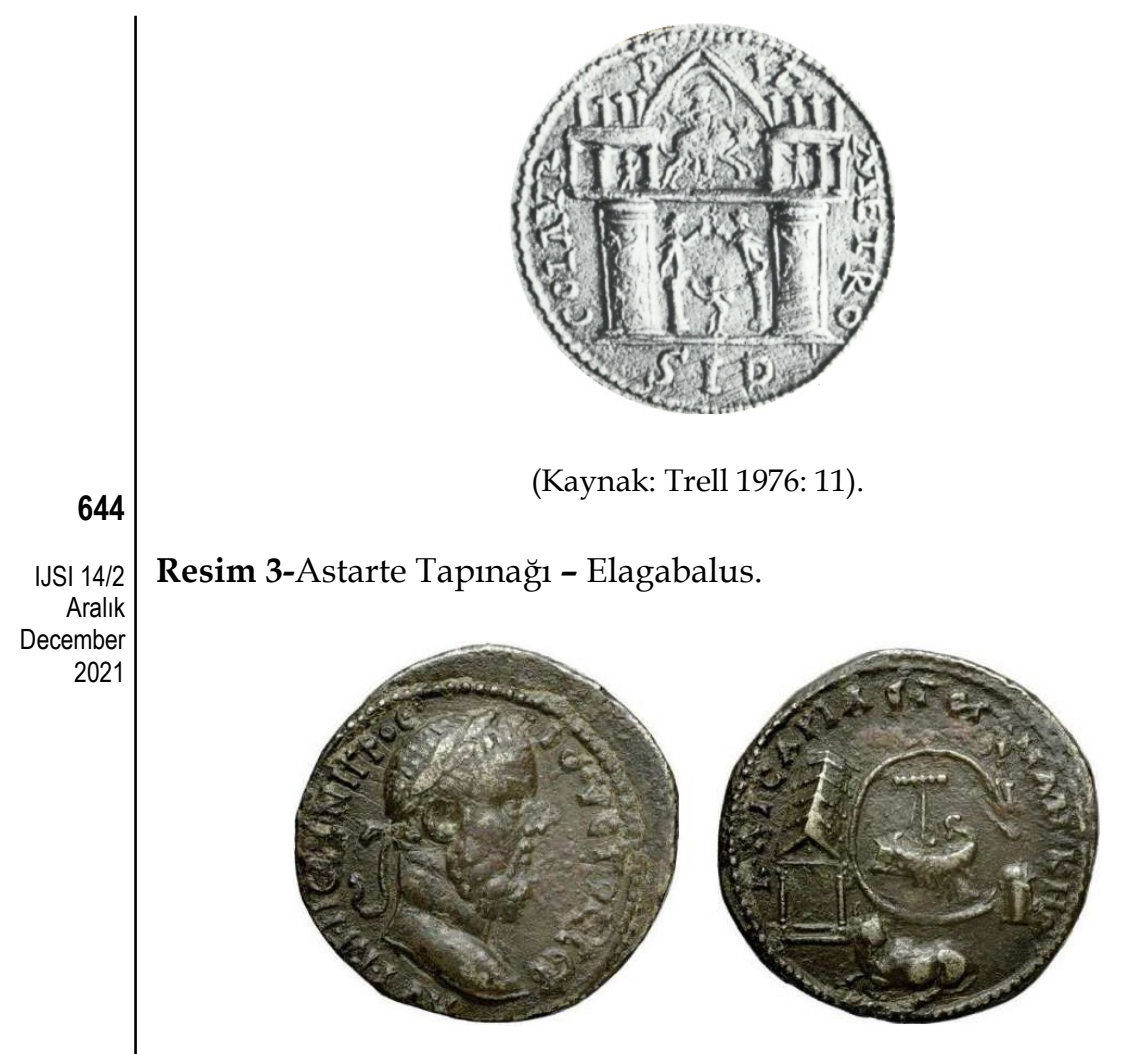

(Kaynak: RG, 1908: 281 No. 5, PL.XLIV/5).

Resim 4-Pescennius Niger Sikkesi.
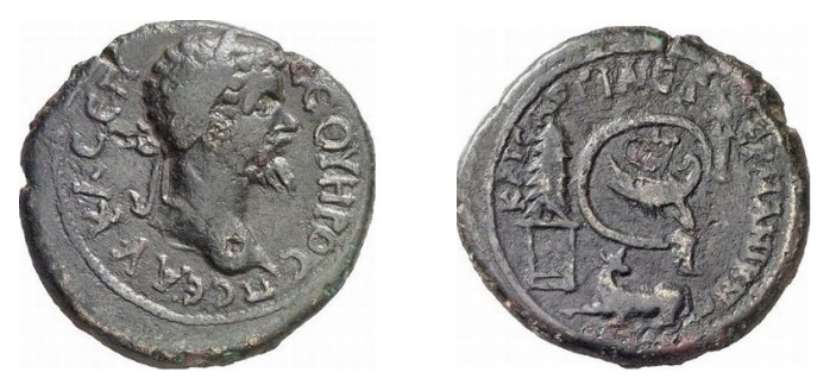

(Kaynak: BMC, 1889: 122 No. 2, Pl.XXVI/10).

Resim 5-Septimius Severus Sikkesi. 

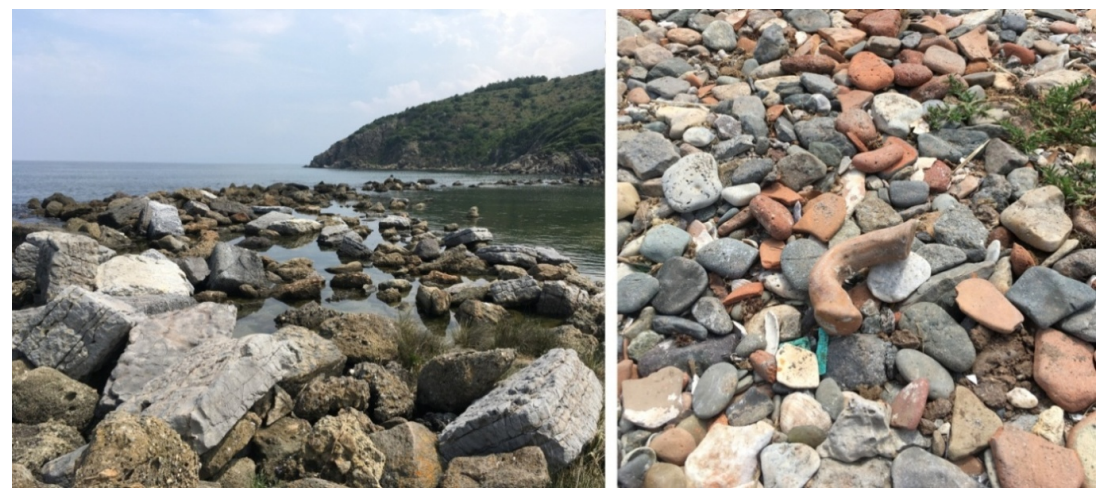

(Kaynak: Yazar).

Resim 6-Liman'da Yer Alan Düzgün Kesilmiş Taş Bloklar ve Seramik Parçaları.
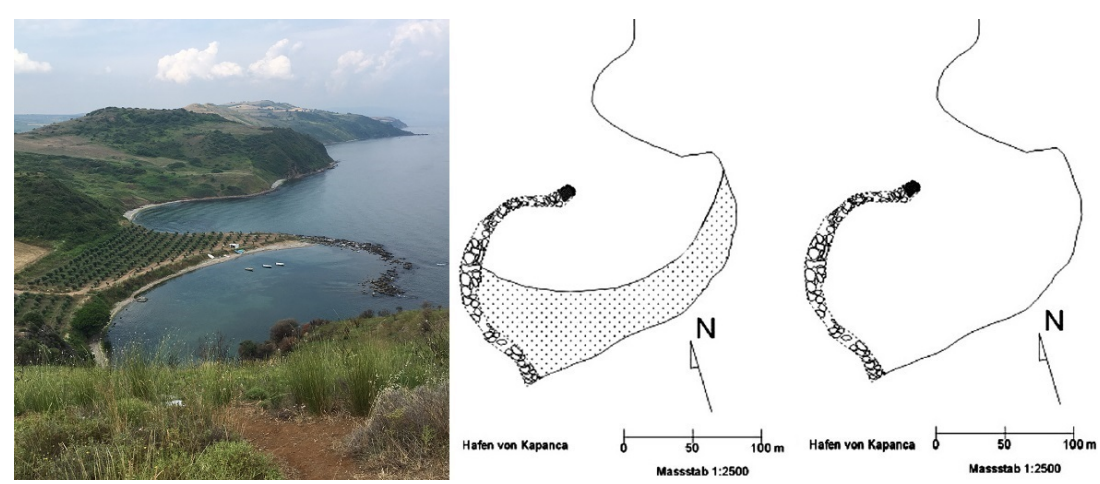

(Kaynak: Fotoğraf: Yazar; Çizim: Şahin vd., 2011: Fig. 9).

Resim 7-Kapanca Liman1.
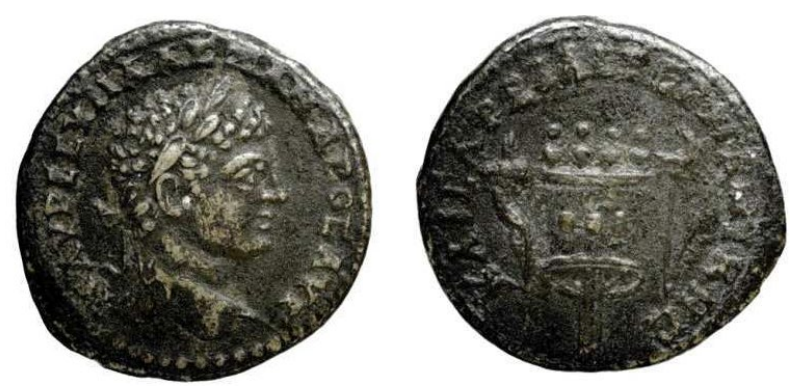

(Kaynak: RG, 1908: 285 No.31, XLV/1).

Resim 8-Severus Alexander Sikkesi. 


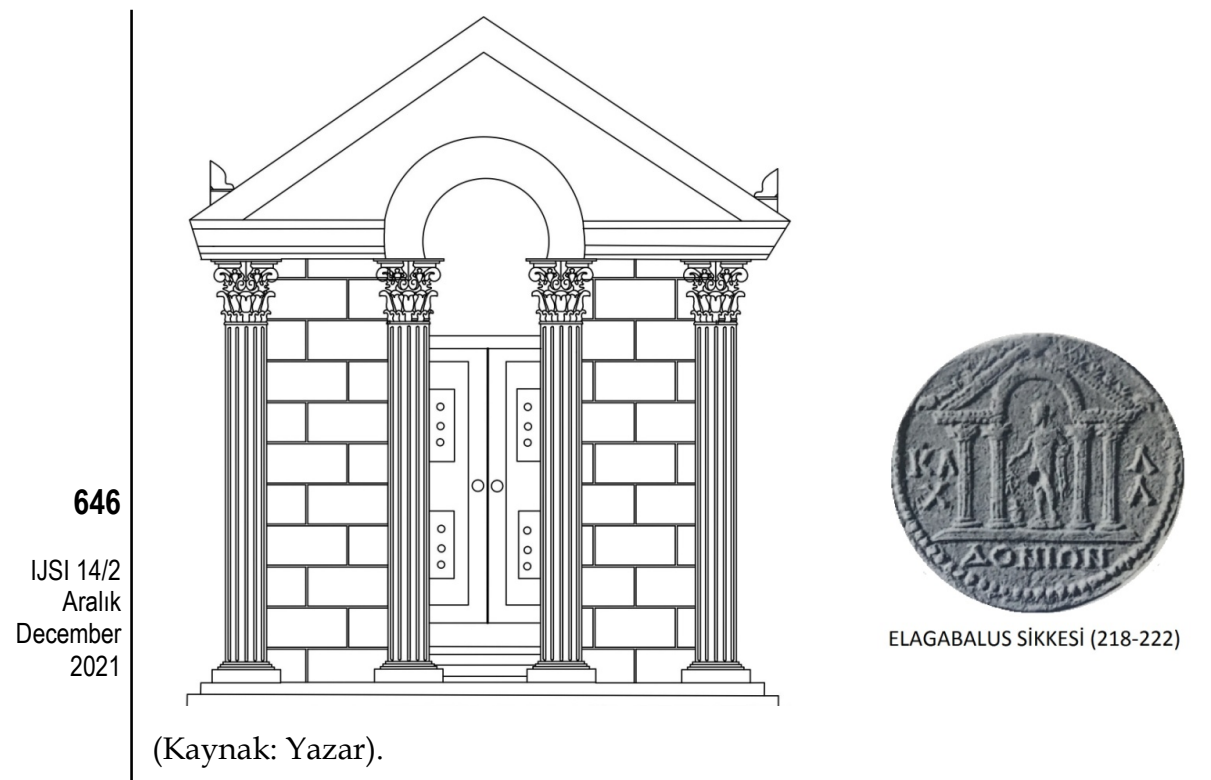

Resim 9- Sikke Betimine Göre Kalkhedon Apollon Tapınağı'nın Olası Öncephe Çizimi.
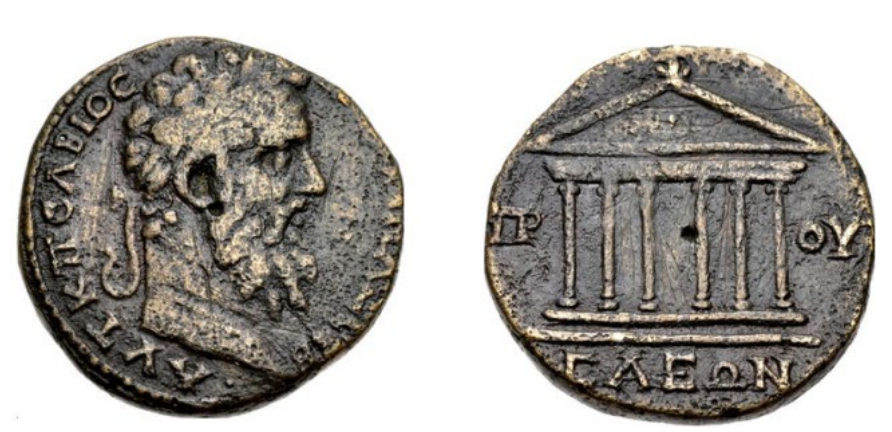

(Kaynak: RG, 1912: 584 No. 65-66).

Resim 10- Pertinax Sikkesi. 


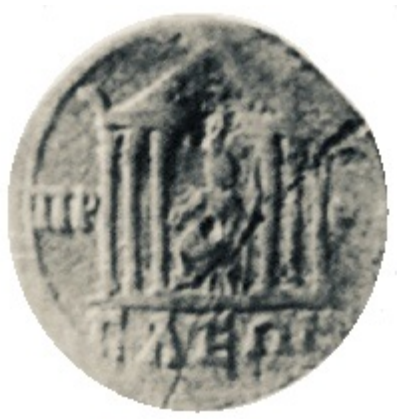

(Kaynak: RG, 1912: 593 No: 7).

Resim 11- Iulia Paula Sikkesi.

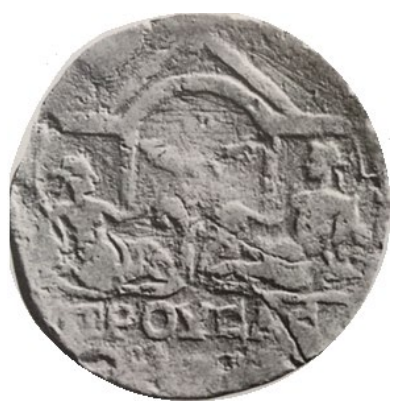

(Kaynak: Marek, 2003: 80, Abb. 12).

Resim 12- Iulia Mamaea Sikkesi.
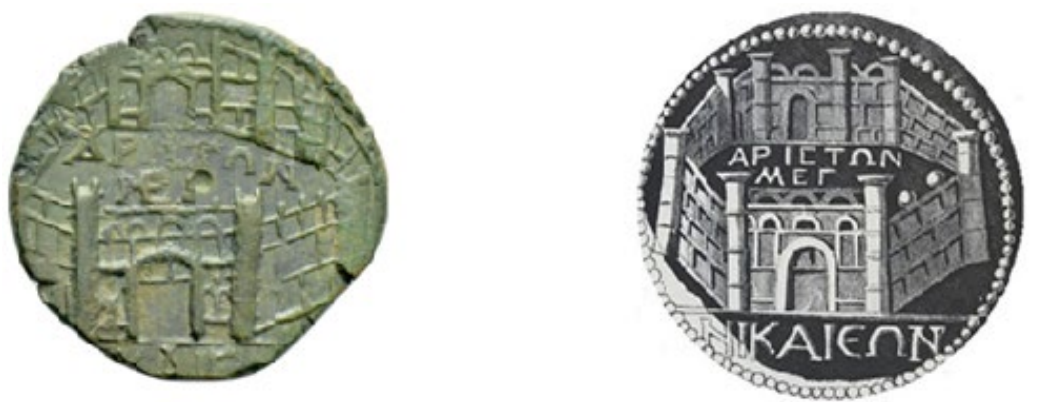

(Kaynak: Görsel: RG, 1910: Pl.LXXXVII/38; Sikke Çizimi: Donaldson, 1965: 323, No. 87).

Resim 13- Gallienus Sikkesi. 


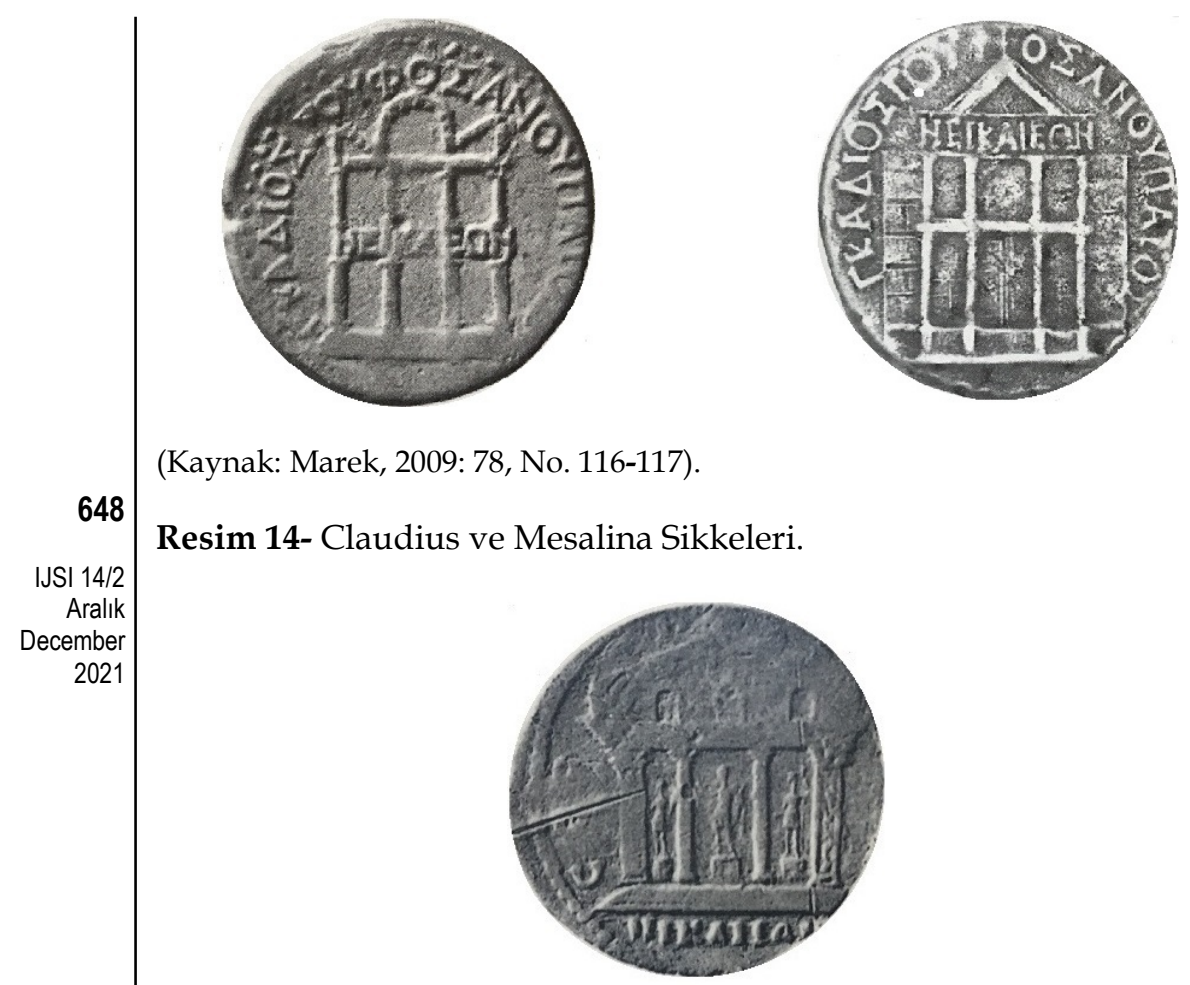

(Kaynak: RG, 1910: 442 No. 346 Pl.LXXVI/4).

Resim 15- Septimus Severus Sikkesi.
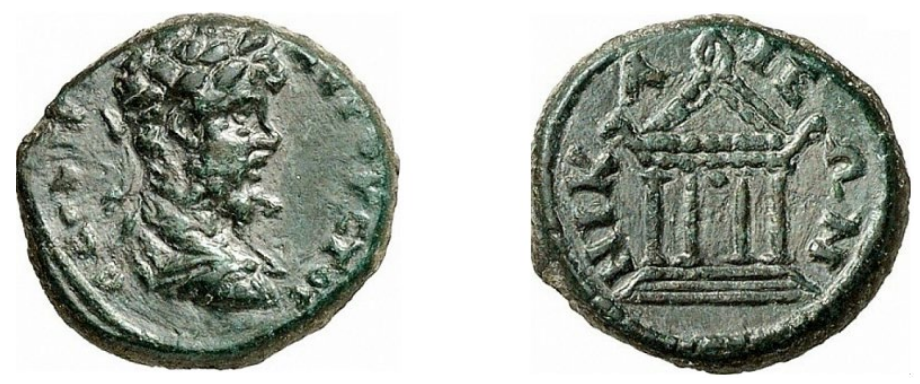

(Kaynak:

http://www.asiaminorcoins.com/gallery/displayimage.php?pid=6639, Erişim Tarihi: 23.12.2018).

Resim 16- Septimius Severus Sikkesi. 

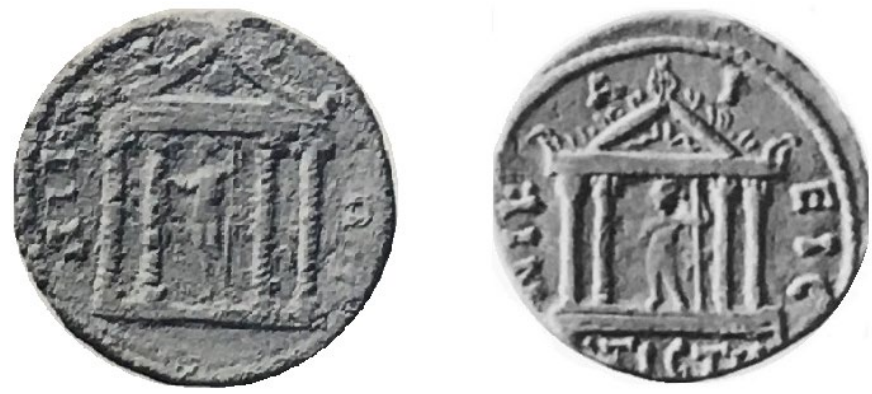

(Kaynak: RG, 1910: 426 No. 219 Pl.LXXII/18; RG, 1910: 418 Pl.LXXII/18).

Resim 17- Dionysos Tapınağını Gösteren Arka Yüz Betimleri.

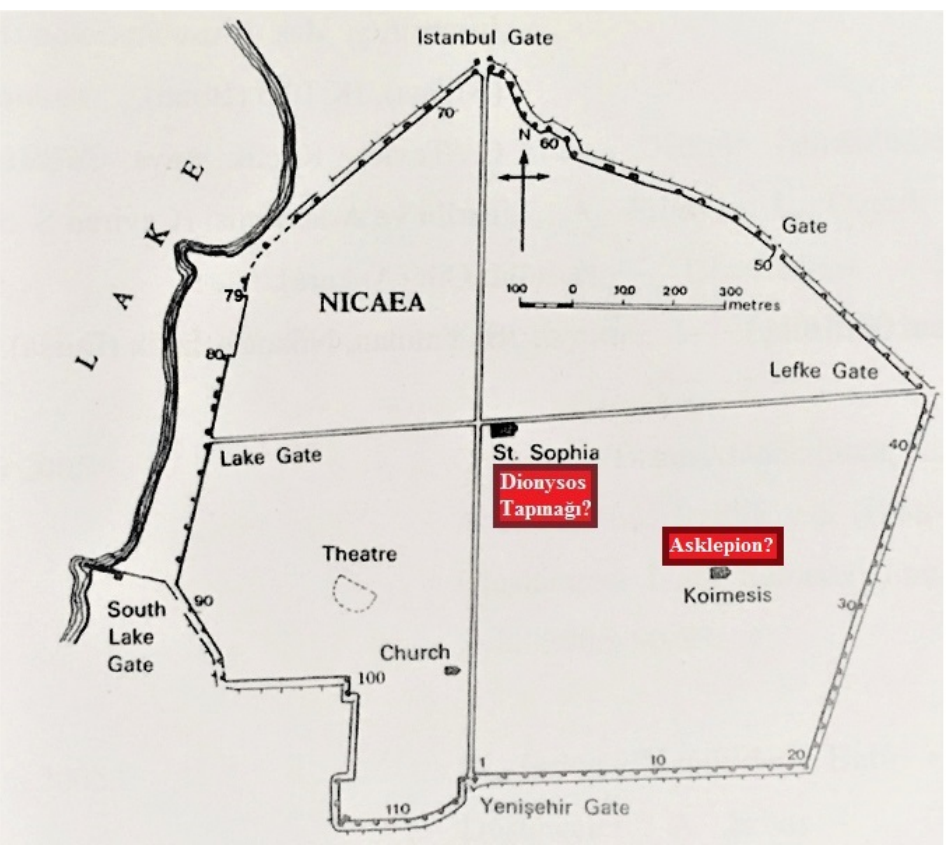

(Kaynak: Foss, Winfield, 1984'den eklemelerle).

Resim 18- Dionysos ve Asklepius Tapınaklarının Olası Lokasyonları. 

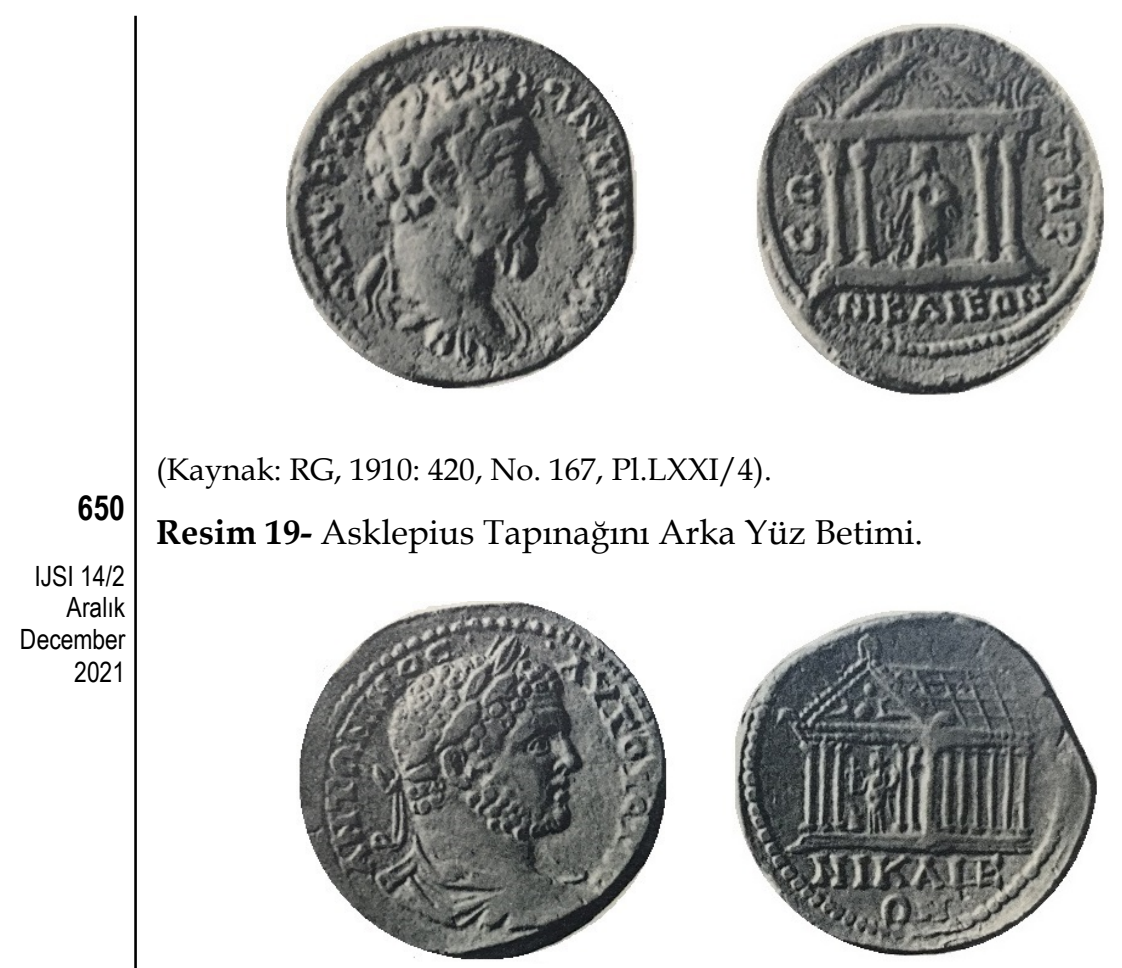

(Kaynak: Weiser, 1983: Taf. 4/46).

Resim 20- Caracalla Sikkesi.
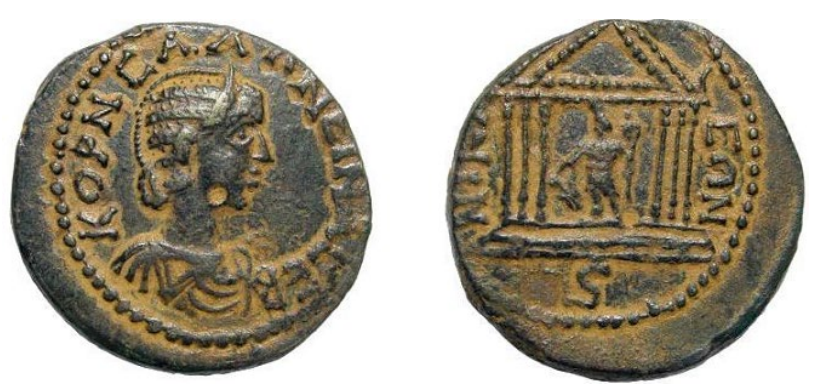

(Kaynak: RG, 1910: 509-863).

Resim 21- Salonina Sikkesi. 


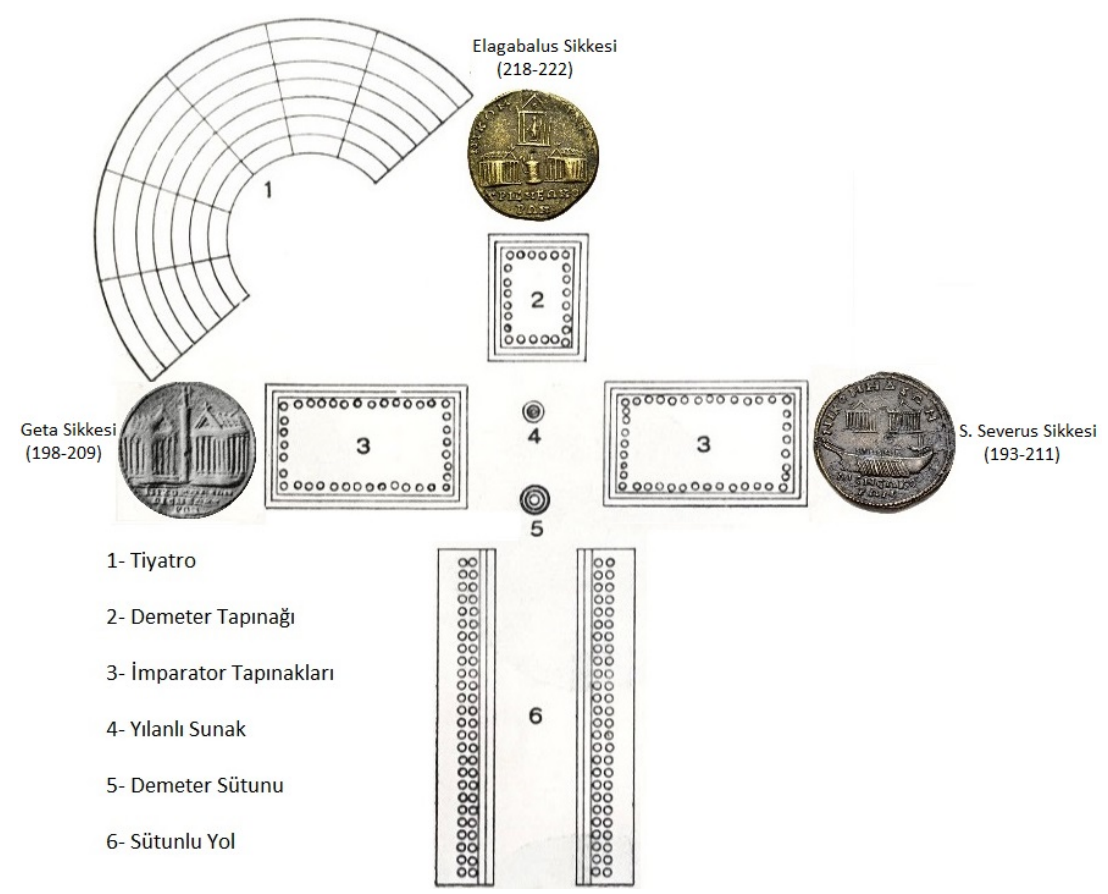

651

IJSI 14/2

Aralık

December

2021

(Kaynak: Bosch,1937: Levha II'den eklemelerle).

Resim 22- Nikomedeia Forumu'nun Sikke Betimlerine Göre Plan Şeması.
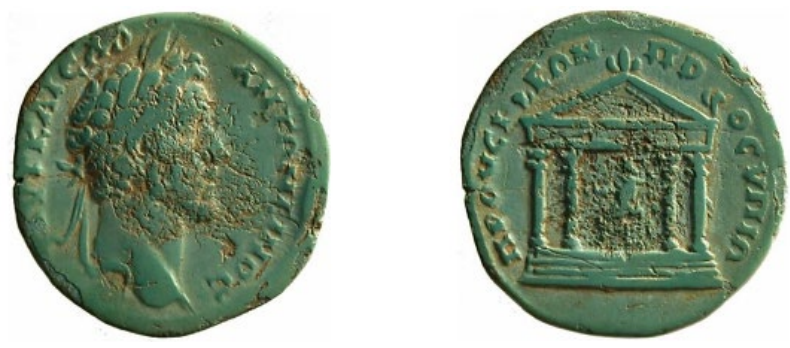

(Kaynak: SNG 1957: Taf. 27/888).

Resim 23- Antonius Pius Sikkesi. 


\section{Metehan IHTIYAR}

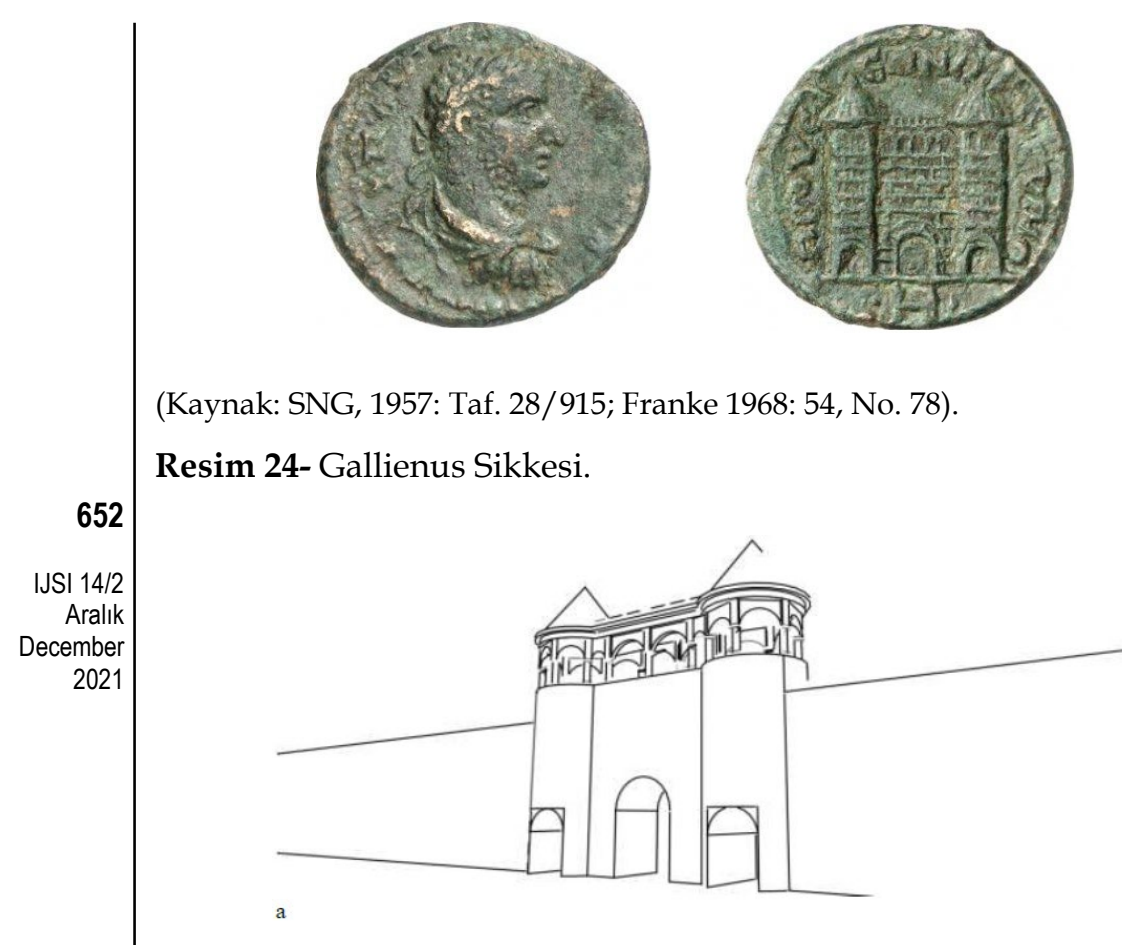

(Kaynak: Karakuş 2017: 274, Ek. 43a).

Resim 25- Prusias ad Hypium Kent Kapısı Olası Görünüm.
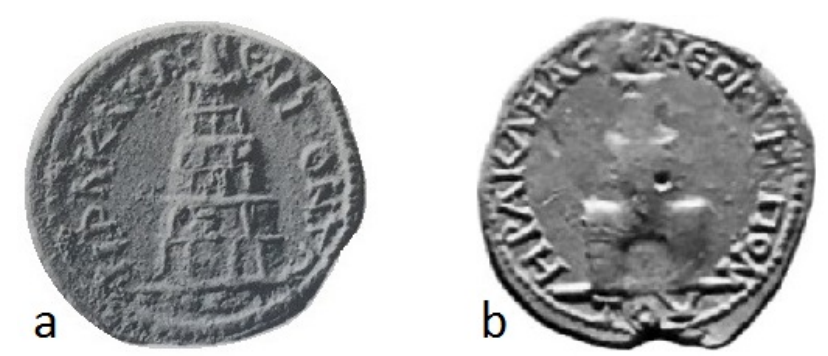

(Kaynak: SNG, 1944: Pl.11/456; RG, 1908: 379 No. 226).

Resim 26- Herakleia Pontika'daki Deniz Kulesi Betimlerini Gösteren Sikkeler. 

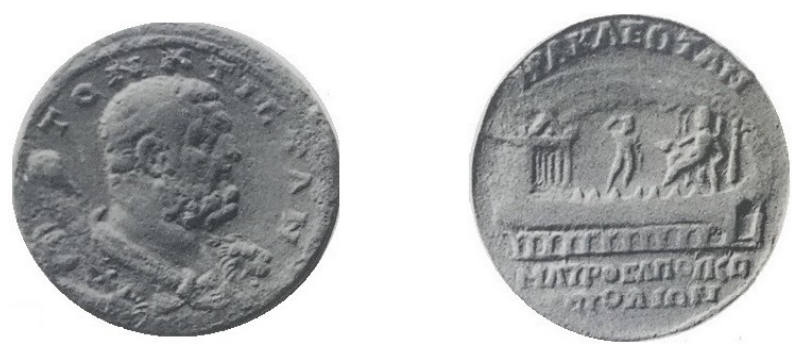

(Kaynak: RG, 1908: 357 No. 76).

Resim 27- III. Gordianus Sikkesi.
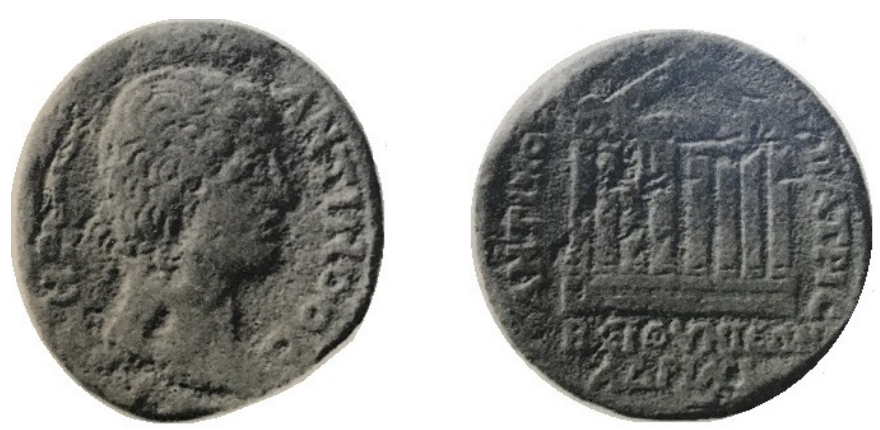

IJSI 14/2

(Kaynak: RG, 1908: 270 No. 18, Pl.XLI/20).

Resim 28-: Hadrianus Sikkesi.
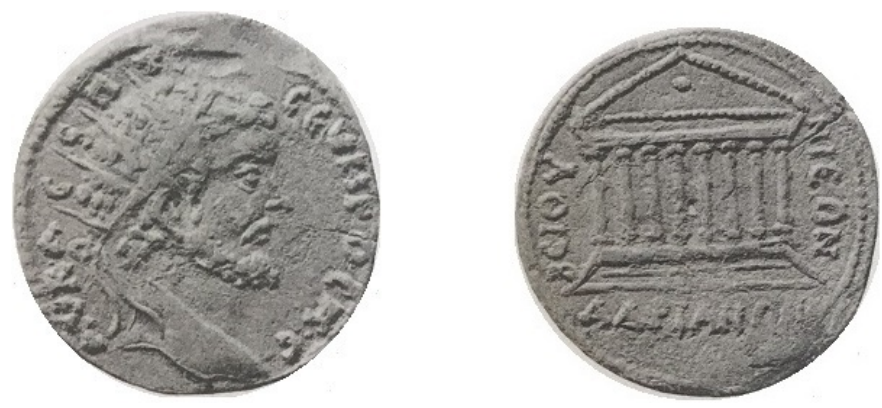

(Kaynak: BMC, 1889: 118, No. 6 Pl.XXVI/4).

Resim 29-: Septimius Severus Sikkesi. 


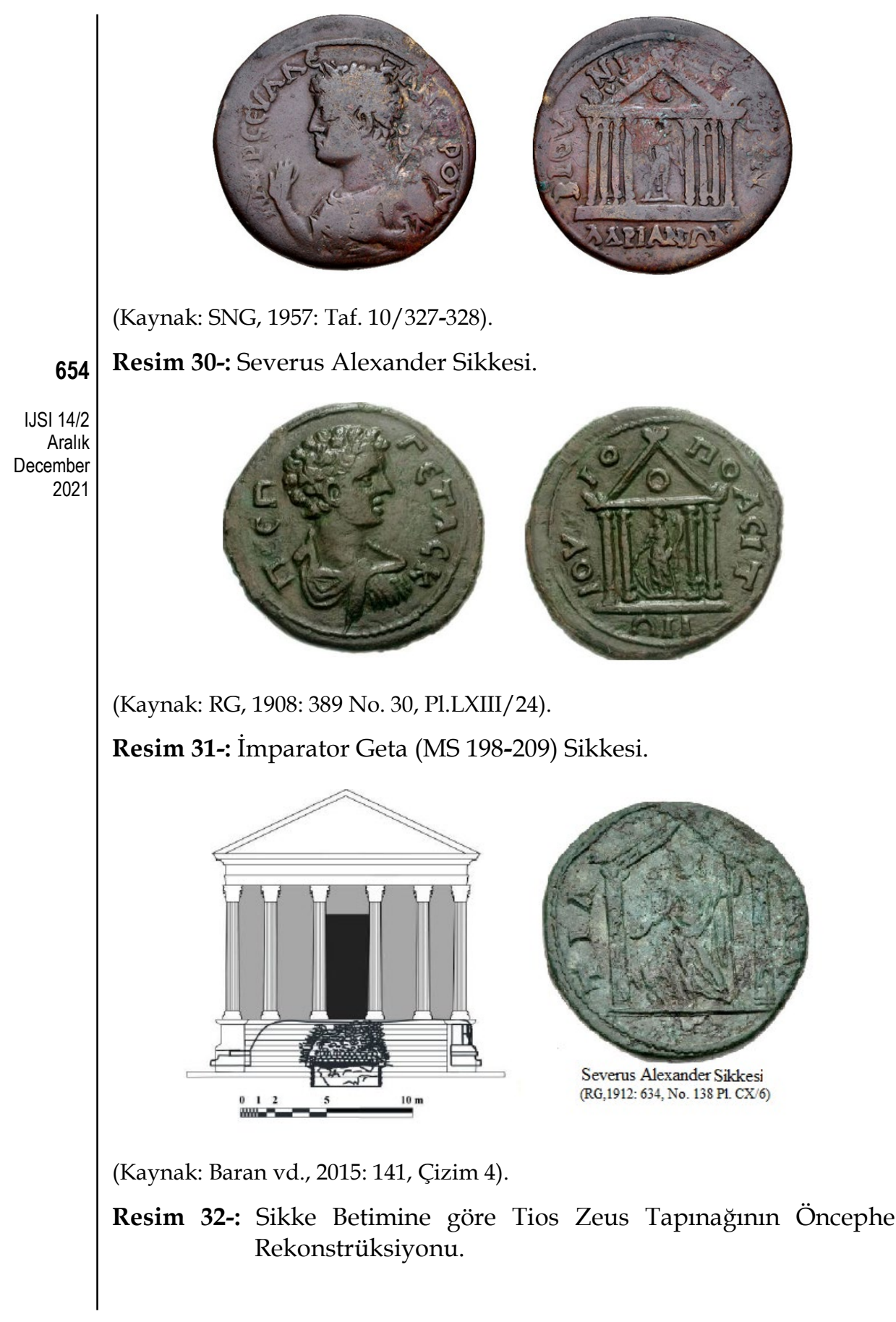



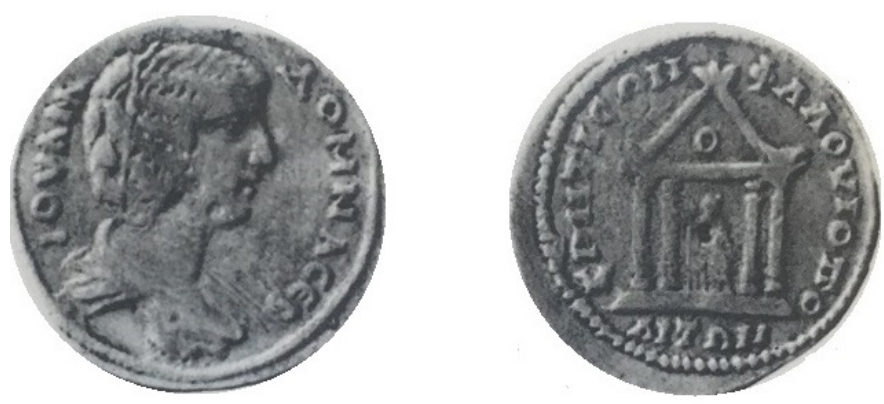

(Kaynak: RG, 1908: 336 No. 19, LIV/6).

Resim 33-: Iulia Domna Sikkesi.
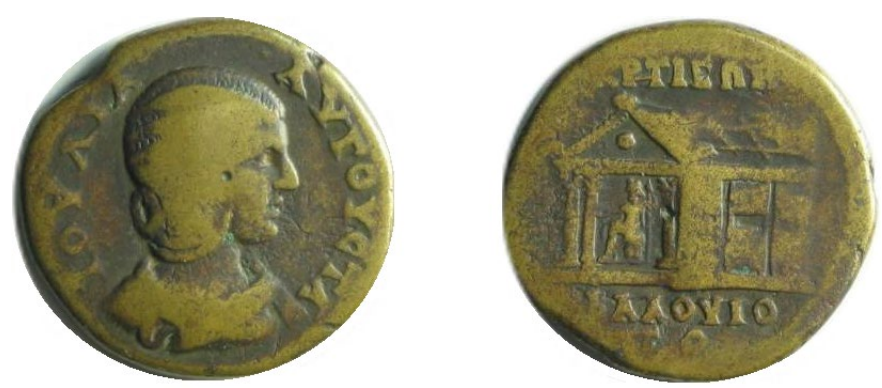

655

IJSI 14/2

Aralık

December

2021

(Kaynak: SNG, 1957: Taf. 16/519).

Resim 34-: Iulia Domna Sikkesi. 


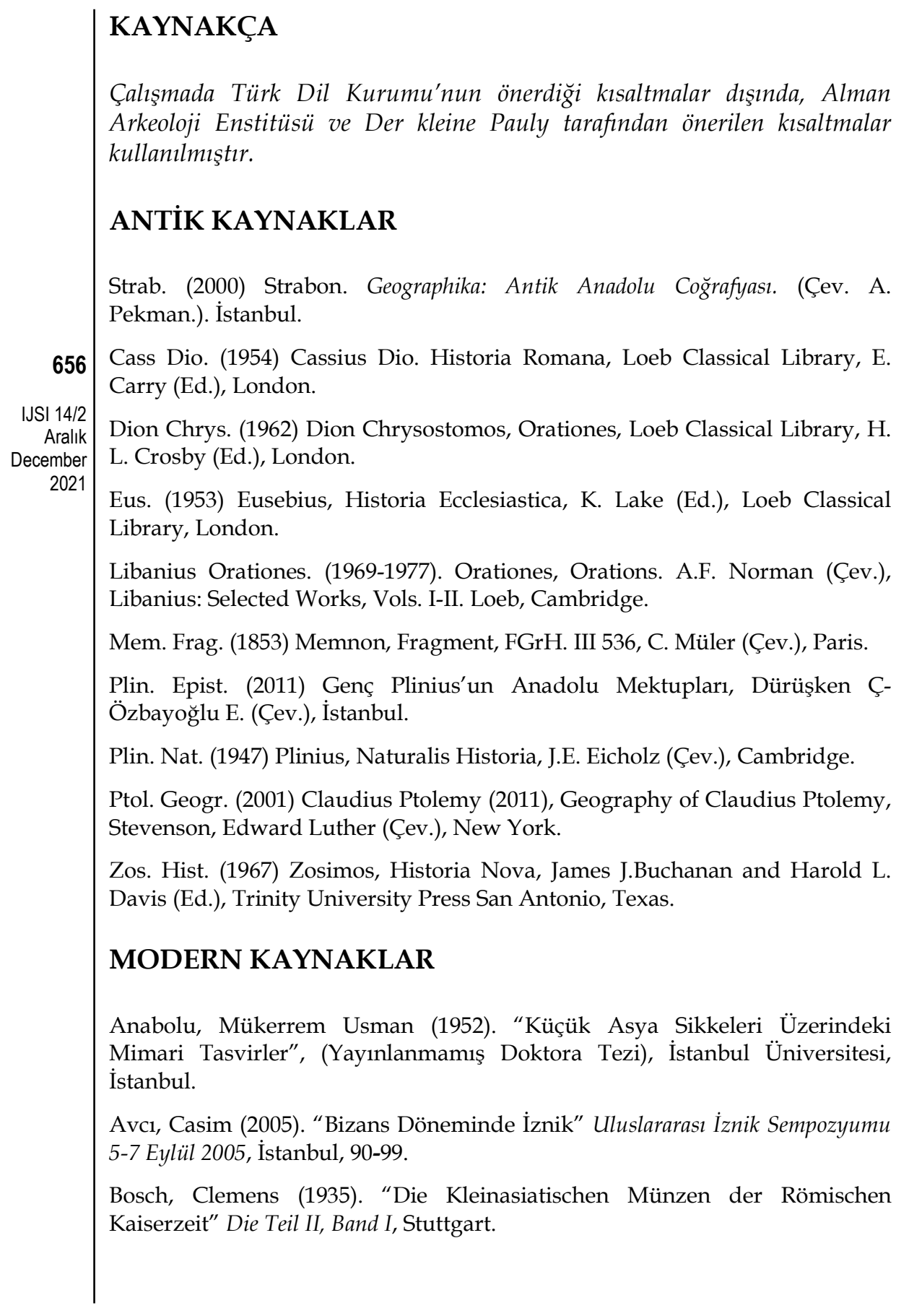


Bosch, Clemens (1937). İzmit Şehrinin Muhasır Tarihi. (Çev. O. Nuri Arıdağ). Ankara: Devlet Basımevi.

Bosch, Clemens (1948). "Nikaia (İznik) Bayram Oyunları". (Çev. Cevriye Artuk), Belleten XII.

Boyana, Hülya (1997). "Bithynia Kültleri ve Tanrıları", (Yayınlanmamış Doktora Tezi), Ankara Üniversitesi Sosyal Bilimler Enstitüsü, Ankara.

Boyana, Hülya (2016), “Nikaia Kenti ve Dionysos Kültü”, Uluslararası Kara Mürsel Alp ve Kocaeli Tarihi Sempozyum Bildirileri - II, 43-59.

BMC, (1889). Catalogue of the Greek Coins, Pontus, Paphlagonia, Bithynia and the Kingdom of Bosphorus, Reginald Stuart Poole (Ed.). London.

Doğanc1, Kamil (2007). “Roma Principatus Dönemi (MÖ 27 - MS 284) Bithynia Eyaleti Valileri (Prosopografik Bir İnceleme)", (Yayınlanmamış Doktora Tezi),Ankara Üniversitesi Sosyal Bilimler Enstitüsü, Ankara.

Donaldson, Thomas Leverton, (1965). Architectura Numismatica or Architectural Medals of Classical Antiquity. London.

Eyice, Semavi (2005). “İznik'ten Hatıralar ve Düşünceler”, Erbaş, A.; Öztürk, L. vd. (Eds.). Uluslararası İnik Sempozyumu 5-7, 327-339.

Foss, Clive; Winfield, David (1984). Byzantine Fortifications An Introductions. University of South Africa.

Filges, Alexis (2015). Münzbild und Gemeinschaft, Die Praegungen der römischen Kolonien in Kleinasien, Frankfurter Archaeologische Schriften 29. Bonn: Verlag Dr. Rudolf Habelt $\mathrm{GmbH}$.

Güçlü, Deniz (2007). “Antik Bithynia Bölgesi'nin Tarihsel İçerikli Yazıtlar Katalogu ve Tarihçesi”, (Yayınlanmamış Yüksek Lisans Tezi), Akdeniz Üniversitesi Sosyal Bilimler Enstitüsü, Antalya.

Haris-Ryde, North (1980). “Bithynia: Roman Sovereignity and the Survival of Hellenism", Temporini, Hildegard (Ed.). ANRW, Berlin-New York: Walter de Gruyter, 857-901.

Imhoof-Blumer, Friederich (1924). Fluss und Meergötter auf Griechischen und Römischen Münzen, Personifikationen der Gaewesser. Winterhurt.

İhtiyar, Metehan (2020). "Myndos Antik Kentinde bir Ayazma Yapısı". IJSI, 13(2), 609-644.

Jones, Arnold Hugh Martin (1937). The Cities of The Eastern Roman Provinces. Oxford.

Kaya, Mehmet Ali (2000). Anadolu'daki Galatlar ve Galatya Tarihi. İzmir: Ege Üniversitesi Edebiyat Fakültesi Yayınları. 


\section{Metehan İHTİYAR}

Kaya, Mehmet Ali (2005). “Anadolu'da Roma Eyaletleri: Sinırlar ve Roma Yönetimi". Tarih Araştırmaları Dergisi, 38(XXIV), 11-30.

Leschhorn, Wolfgang (1998). “Die Verbreitung von Agonen in den Östlichen Provinzden des Römischen Reiches" Stadion XXIV- 1. Colloquium, Akademia Verlag, Münster, 31-57.

Macro, Antony (1980). "The Cities of Asia Minor Under the Roman Imperium", Temporini, Hildegard (Ed.). ANRW, Berlin-New York: Walter de Gruyter, 659-695.

Magie, David (1950). Roman Rule in Asia Minor to the end of the third century after Christ I-II. Princeton.

Marek, Christian (2003). Bithynia et Pontus, Die römischen Provinzen im Norden Kleinasiens. Berlin: Verlag Philipp Von Zabern.

Marek, Christian (2009). "Hellenisation and Romanisation in Pontus-Bithynia: An Overview". 36-45.

Matheson, Susan (1994). “The Goddess Tykhe”. New Haven, 18-33.

Merkelbach, Reinhold (1978). “Der Rangstreit der Staetde Asiens und Rede des Aelius Asistides über die Eintracht". ZPE, 32, 287-296.

Öztürk, Bülent (2013a). “Herakleia Pontika (Zonguldak-Karadeniz Ereğli) Antik Kenti Epigrafik Çalışmaları ve Tarihsel Sonuçları", I. Uluslararası Karadeniz Kültür Kongresi Bildiri Kitabı (Sinop), 505-527.

Öztürk, Bülent (2013b). “Tios / Teion (Zonguldak-Filyos) Antik kenti Epigrafik Çalışmaları ve Tarihsel Sonuçları", I. Uluslararası Karadeniz Kültür Kongresi Bildiri Kitabı (Sinop), 485-504.

Price, Martin Jessop (1967). “Countermarks at Prusias ad Hypios”. NumChron, 7.7, 37-42.

Price, Martin Jessop; Trell, Bluma (1977). Coins and Their Cities. Architecture on the Ancient Coins of Greece, Rome and Palestine. London.

Price, Simon (2004). Ritüel ve İktidar - Küçük Asya'da Roma İmparatorluk Kültü. (Çev. T. Esin). Ankara.

Ruge, Walter (1936). “Nikaia”. RE, XVII, 218-243.

RG (1908). Recueil Général des Monnaies Mineure 1/3. Waddington, W. H.; Babelon, E.; Reinach, T. (Eds.). Paris.

RG (1910). Recueil Général des Monnaies Mineure 1/3. Waddington, W. H.; Babelon, E.; Reinach, T. (Eds.). Paris.

RG (1912). Recueil Général des Monnaies Mineure 1/4. Waddington, W. H.; Babelon, E.; Reinach, T. (Eds.). Paris. 


\section{Bıthynı Bölgesi Roma Dönemi Mimari Betimli Kent Sikkeleri}

Sear, David (1982). Greek Imperial Coins. London: Seaby's Numismatic Publications Ltd.

SNG (1944). Sylloge Nummorum Graecorum. The Royal Collection of Coins and Medals: Bosporus-Bithynia. Copenhagen: Danish National Museum.

SNG (1957). Sylloge Nummorum Graecorum: Deutschland. Sammlung v Aulock, Pontus-Paphlagonien-Bithynien. Berlin.

Şahin, Mustafa (2009). “Sikke Betilerine Göre Roma Çağı Nikaia'sında (İznik) Yapı Programı". Bursa Araştırmaları Kent Tarihi ve Kültürel Dergisi, 26, Bursa, 15-21.

Şahin, Mustafa; Polat, Yasemin; Zimmerman, Thomas (2011). “Der Hafen von Kapanca: Ein Neuer Vorschlag Zur Lokalisation der Stadt Caesarea Germanica". OLBA, XIX, 203-232.

Şahin, Mustafa; Mert, İbrahim Hakan (2011). Uluslar Arası İznik I. Konsil Senato Sarayı' nın Lokalizasyonu Çalıştayı Bildirileri, Bursa.

Trell, Bluma (1976). "Architecture on Ancient Coins". Archaeology, 29(1), Archaeogical Institute of America, 6-13.

Weiser, Von Wolfram (1983). Katalog Der Bithynischen Münzen der Sammlung ses Instituts für Altertumskunde der Universitaet zu Köln, Vol. XI, Band 1, Nikaia. Köln.

Wilson, David Rould (1961). The Historical Geography of Bithynia, Paphlagonia and Pontus in the Greek and Roman Periods. Oxford University. 
Metehan İHTIYYAR

\section{SUMMARY}

The Ancient Bithynia is a geography that has hosted many civilizations throughout the history and has hosted many important cities. After the Bithynia Region became a province of the Roman Empire, construction activities started and within this scope, structures such as city walls, temples, theaters, lighthouses, harbour structures and gymnasions were built. These monumental and public buildings that adorn the city are frequently depicted on coins minted during the Roman Period. In this article, the lost or still existing construction depicting on architectural coins struck in the cities of Bithynia during the Roman Period were examined. These cities are geographically west to east; consists of Kaisareia Germanika, Chalcedon,

Prusa ad Olympum, Nikaia, Nikomedeia, Prusa ad Hypium, Herakleia Pontika, Bithynion, Iuliopolis, Tios and Kreteia. The subject of the article is examined under two parts in accordance with the investigation method. In the first part is handled the subject of the importance of the architectural depiction coins in scientific studies and the design methods of the moneyers. The second part is the most comprehensive part of the article. In this section, firstly, the informations is given about the history of the cities of Bithynia minted the architectural coinage and then the architectural depictions of coins minted by these cities are explained in detail. In the light of the coins examined, the possible architectural structures of the ancient cities in Bithynia and were clarified the locations of these structures. The location of many structures depicted on the coins is unknown. However, according to the comparisons made with similar city plans, it is thought that the locations of the temples in question should be searched around the existing churches. As many pagan temples were converted into churches during the transition from pagan belief to Christianity in ancient times. The temples depicted on the coins were dedicated to gods and goddesses such as Zeus, Dionysus, Demeter, Asklepius, Apollon and Fortuna, who were respected in these cities according to their iconographic features. In addition, it is understood that many buildings such as the theater, stadion and circus were built for the agon games performed on behalf of the emperors. In this article, the ideological significance of Roman coins conceptualized in their historical context is also examined. Accordingly, the architectural structures built by the empire were represented on the reverse of the coins and it was understood that they were used as a political propaganda purpose thanks to the financial assistance of the Roman Emperors. Accordingly, it is understood that the architectural structures represented on the reverse of the coins were used as a political propaganda purpose thanks to the financial assistance of the Roman Emperors. 